University of Tennessee Health Science Center

UTHSC Digital Commons

\title{
Therapeutic Potential of TRP Channels in the Targeting of Rheumatoid Arthritis Synovial Fibroblasts
}

\author{
Brittany Isabella Schwam \\ University of Tennessee Health Science Center
}

Follow this and additional works at: https://dc.uthsc.edu/dissertations

Part of the Immune System Diseases Commons, Medical Biophysics Commons, Medical Cell Biology Commons, Medical Immunology Commons, and the Medical Molecular Biology Commons

\section{Recommended Citation}

Schwam, Brittany Isabella (https://orcid.org/0000-0003-4372-4861), "Therapeutic Potential of TRP Channels in the Targeting of Rheumatoid Arthritis Synovial Fibroblasts" (2021). Theses and Dissertations (ETD). Paper 549. http://dx.doi.org/10.21007/etd.cghs.2021.0530.

This Thesis is brought to you for free and open access by the College of Graduate Health Sciences at UTHSC Digital Commons. It has been accepted for inclusion in Theses and Dissertations (ETD) by an authorized administrator of UTHSC Digital Commons. For more information, please contact jwelch30@uthsc.edu. 


\title{
Therapeutic Potential of TRP Channels in the Targeting of Rheumatoid Arthritis Synovial Fibroblasts
}

\begin{abstract}
Rheumatoid arthritis is a chronic inflammatory disease primarily affecting the synovium, articular cartilage, and bone within a joint, but it is a unique form of arthritis wherein effects are systemic. The cause of this autoimmune disease remains unknown, but there are many environmental and genetic factors that play into susceptibility. Research is still far from drug-free remission despite great advancements over the past few decades. The majority of therapies developed rely on immunosuppressant or immunomodulator molecules and come with risk of infection, high costs, and toxic, uncontrolled side effects. Those diagnosed maintain a significant unmet need for targeted therapies.

There is increasing evidence towards non-immune cell types in the joint as the culprit for the changes in anatomy of the joint at disease onset. A thin lining called the synovium covers the joint cartilage and acts as a barrier which secretes synovial fluid that lubricates the joint. Synovial fibroblasts, also called fibroblast-like synoviocytes, are responsible for this secretion of lubricating components hyaluronic acid and lubricin that allow for ease of movement. Together with macrophages, they make up the synovial lining and sub-lining in roughly equal proportion. Proinflammatory cytokine production in the inflamed joint leads to synovial fibroblast proliferation and transforms these cells into a "tumor-like" phenotype with the capacity to degrade cartilage and bone. Synovial fibroblasts perpetuate the destruction of articular cartilage by producing matrix-degrading enzymes, cytokines, and increasing production of adhesion molecules to attach and build on to cartilage. The synovium thickens and the cartilage and bone in the joint is broken down, and synovial fibroblasts recruit more immune cells to the joint to further exacerbate joint destruction. This positive feedback loop makes synovial fibroblasts a desirable target for anti-rheumatic drugs

An abundance of research implicating TRP channels in rheumatoid arthritis synovial fibroblasts pathogenic phenotype has accumulated over the past decade. Studies of the rheumatoid synovium demonstrate the expression of several of these channels including TRPV1, TRPV2, TRPV4, TRPA1, TRPM7, TRPM8, and more. The channels' direct implication in synovial fibroblast aggressive phenotype is becoming better understood and shows promise for TRP channels as therapeutic targets. My master's thesis will focus on TRP channel involvement in mechanisms by which synovial fibroblasts evade apoptosis, proliferate, degrade the joint, and migrate to unaffected joints in order to understand these biological sensors as potential rheumatoid arthritis therapeutic candidates.
\end{abstract}

\section{Document Type}

Thesis

\section{Degree Name}

Master of Science (MS)

\section{Program}

Biomedical Sciences

\section{Research Advisor}

Valeria Vasquez, PhD 


\section{Keywords}

BH3-mimetics; HRI; MCL-1

\section{Subject Categories}

Diseases | Immune System Diseases | Medical Biophysics | Medical Cell Biology | Medical Immunology | Medical Molecular Biology | Medical Sciences | Medicine and Health Sciences 
MASTER OF SCIENCE THESIS

\section{Therapeutic Potential of TRP Channels in the Targeting of Rheumatoid Arthritis Synovial Fibroblasts}

Author:

Advisor:

Brittany Isabella Schwam

Valeria Vásquez, $\mathrm{PhD}$

A Thesis Presented for The Graduate Studies Council of

The University of Tennessee Health Science Center

in Partial Fulfillment of the Requirements for the Master of Science degree from

The University of Tennessee

in

Biomedical Sciences: Molecular and Translational Physiology

College of Graduate Health Sciences

April 2021 
Copyright () 2021 by Brittany Schwam. All rights reserved. 


\section{ACKNOWLEDGEMENTS}

I would like to thank my advisor, Dr. Valeria Vásquez, who mentored me in many ways and went the extra mile to provide academic and professional guidance to not only me, but many students. I'd also like to thank my committee members, Dr. Helena Parfenova and Dr. Elizabeth Fitzpatrick for their support on my committee and throughout my training in the College of Graduate Health Sciences at the University of Tennessee Health Science Center. I would like to thank my instructors, especially Dr. Zheng Fan, for the training in the classroom that translated meaningfully in the lab.

I would also like to thank all of the Physiology department faculty who were mentors and instructors to me as well as other Physiology track students. I would like to broadly thank the friends and peers that I have had the honor of studying and researching alongside in the biomedical sciences program for their support and encouragement- a special thanks to Physiology track friends Briar Bell, Chris Pitzer, Hector Paez, Jesse Gammons, and Jerry Afolabi for those essential exam study sessions, supportive advice, and constant laughs. I would like to thank postdoctoral fellow and senior graduate friends, Dr. Efren Maldonado, Dr. Rebeca Caires, Dr. Alejandro Mata-Daboin, Dr. Geetika Singh, Dr. Janet Zheng, Dr. Anup Aggarwal, and Dr. Avtar Meena, for their support, mentorship, and friendship along the way.

I would like to thank all my friends and colleagues from St. Jude Children's Research Hospital for the training and experience in academia that has prepared me for my career, and their Chemical Biology and Therapeutics department that allowed me to use their resources in order to experience a bit of high-throughput, industry-level workflow in my independent project. Finally, I would like to thank my family and my husband for the encouragement and support in this program and in everything- to my parents for always supporting a curious mind, to my husband for always believing in me, to my grandparents, sisters, family-in-law, and friends who are really more like family, for their cheering along the way. 


\begin{abstract}
Rheumatoid arthritis is a chronic inflammatory disease primarily affecting the synovium, articular cartilage, and bone within a joint, but it is a unique form of arthritis wherein effects are systemic. The cause of this autoimmune disease remains unknown, but there are many environmental and genetic factors that play into susceptibility. Research is still far from drug-free remission despite great advancements over the past few decades. The majority of therapies developed rely on immunosuppressant or immunomodulator molecules and come with risk of infection, high costs, and toxic, uncontrolled side effects. Those diagnosed maintain a significant unmet need for targeted therapies.
\end{abstract}

There is increasing evidence towards non-immune cell types in the joint as the culprit for the changes in anatomy of the joint at disease onset. A thin lining called the synovium covers the joint cartilage and acts as a barrier which secretes synovial fluid that lubricates the joint. Synovial fibroblasts, also called fibroblast-like synoviocytes, are responsible for this secretion of lubricating components hyaluronic acid and lubricin that allow for ease of movement. Together with macrophages, they make up the synovial lining and sub-lining in roughly equal proportion. Proinflammatory cytokine production in the inflamed joint leads to synovial fibroblast proliferation and transforms these cells into a "tumor-like" phenotype with the capacity to degrade cartilage and bone. Synovial fibroblasts perpetuate the destruction of articular cartilage by producing matrix-degrading enzymes, cytokines, and increasing production of adhesion molecules to attach and build on to cartilage. The synovium thickens and the cartilage and bone in the joint is broken down, and synovial fibroblasts recruit more immune cells to the joint to further exacerbate joint destruction. This positive feedback loop makes synovial fibroblasts a desirable target for anti-rheumatic drugs

An abundance of research implicating TRP channels in rheumatoid arthritis synovial fibroblasts pathogenic phenotype has accumulated over the past decade. Studies of the rheumatoid synovium demonstrate the expression of several of these channels including TRPV1, TRPV2, TRPV4, TRPA1, TRPM7, TRPM8, and more. The channels' direct implication in synovial fibroblast aggressive phenotype is becoming better understood and shows promise for TRP channels as therapeutic targets. My master's thesis will focus on TRP channel involvement in mechanisms by which synovial fibroblasts evade apoptosis, proliferate, degrade the joint, and migrate to unaffected joints in order to understand these biological sensors as potential rheumatoid arthritis therapeutic candidates. 


\section{TABLE OF CONTENTS}

\section{CHAPTER 1. INTRODUCTION TO RHEUMATOID ARTHRITIS}

SYNOVIAL FIBROBLASTS

\section{.1}

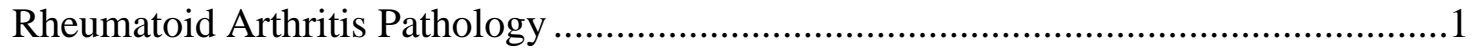

Current Treatment Options for Rheumatoid Arthritis ..............................................

Synovial Fibroblasts in the Pathology of Rheumatoid Arthritis ...................................4

TRP Channel Involvement in Rheumatoid Arthritis ................................................5

\section{CHAPTER 2. TRP CHANNELS AS THERAPEUTIC CANDIDATES FOR} RHEUMATOID ARTHRITIS...............................................................................9

TRP Channel Family Characterization .................................................................. 9

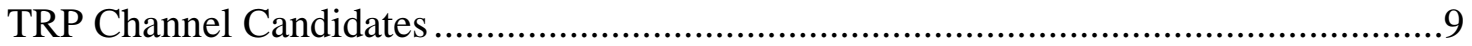

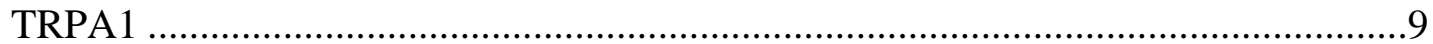

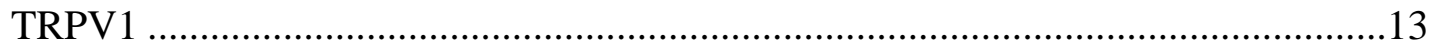

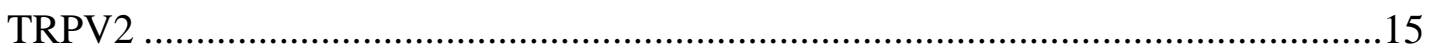

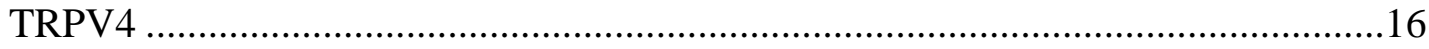

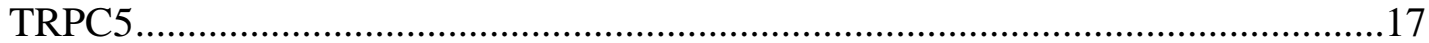

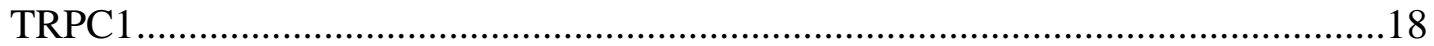

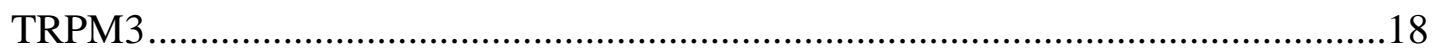

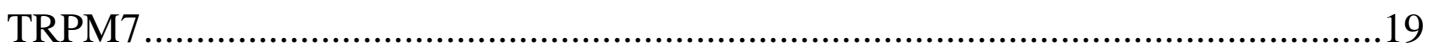

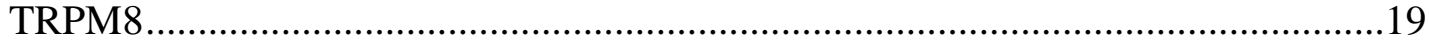

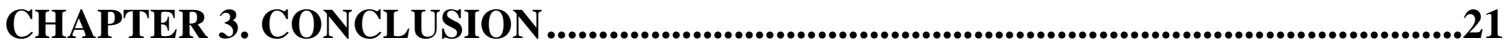

Overview of TRP Channel Contribution to RA Synovial Fibroblast Activity ..............21

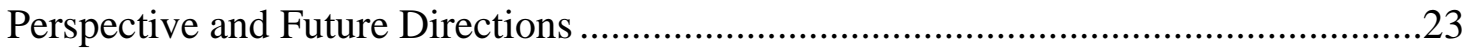

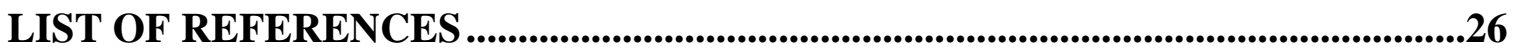

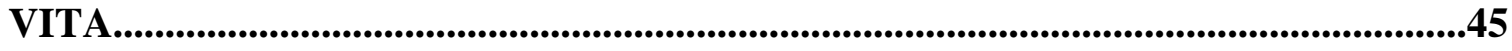




\section{LIST OF TABLES}

Table 1-1. Discovery of TRP Channel Presence and Activity in Rheumatoid

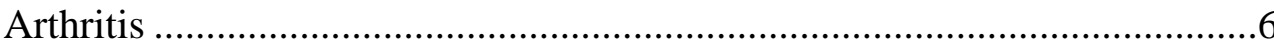

Table 3-1. Proposed Actions to Target TRP Channels Candidacy to Ameliorate Rheumatoid Arthritis Symptoms. 


\section{LIST OF FIGURES}

Figure 1-1. Synovium of the Joint in Health Versus Rheumatoid Arthritis ....................2

Figure 2-1. TRP Channel Phylogenetic Tree............................................................10

Figure 3-1. Activated Synovial Fibroblast Mechanisms Involving TRP Channels.........24 


\section{CHAPTER 1. INTRODUCTION TO RHEUMATOID ARTHRITIS SYNOVIAL FIBROBLASTS}

Rheumatoid arthritis (RA) is a chronic inflammatory disease affecting millions of lives and is steadily increasing over time (1-3). Arthritis is a leading cause of disability among adults, and RA is one of the most common types. John Hopkins Arthritis Center reports that RA has a worldwide distribution and incidence of 1 to $2 \%$ (2). The socioeconomic and health burden of RA on society grows as the life expectancy rises (3, $4,6)$. Most RA sufferers go roughly a year without treatment from the time of symptom onset. In that time, disease progression can be costly with irreversible damage, as the bulk of joint damage occurs in the first two years $(2,5)$. In addition, mortality hazards such as heart disease are extremely elevated in patients with RA compared to the general population. In 2010, approximately one-fourth to one-half of all patients with RA became unable to work within 10-20 years of following diagnosis $(2,3)$. Recent meta-analysis data estimates direct medical costs in the US are $\$ 12,509$ to $\$ 36,053$ for RA patients in a treatment regimen (4).

\section{Rheumatoid Arthritis Pathology}

RA is a chronic inflammatory disease with unknown cause and is a unique form of arthritis because the systemic mechanisms go beyond joint destruction and can attack other organs $(9,11)$. Genetic factors and environmental risk (e.g., smoking) can both contribute to the pathogenesis and progression of RA. RA primarily affects the synovium, articular cartilage, and bone within a joint, often with symmetrical distribution as the disease progresses (Figure 1-1) (2, 6). RA causes chronic swelling and pain in movable joints and can cause permanent disability of the affected joints $(6,22)$. The strongest correlations are to gender, obesity, and age (2, 3, 6-10, 22). Disease onset can be detected by physical attributes such as painful joint swelling as well as detection of antibodies commonly produced in autoimmune diseases. The process of autoimmunity begins with the immune system confusing molecules and cells in the body as foreign invaders. Eventually, the immune system hoists attack on the body. In RA, this manifests mainly in the joints $(2,6)$. Diagnostic tests are used to analyze sera for markers such as antibodies called rheumatoid factors or high levels of proinflammatory cytokines that target the inflamed joint in particular $(2,9)$. Once diagnosed, patients must maintain a treatment regimen to suppress inflammation and further joint damage.

\section{Current Treatment Options for Rheumatoid Arthritis}

Current treatment options are far from offering drug-free remission, though there have been advancements in the efficacy of available medicine in the past few decades (12). Patients are diagnosed based on the presence of certain autoantibodies and symptoms such as synovitis, in which the affected joint swells, and joint pain and 
A)

\section{Healthy Joint}

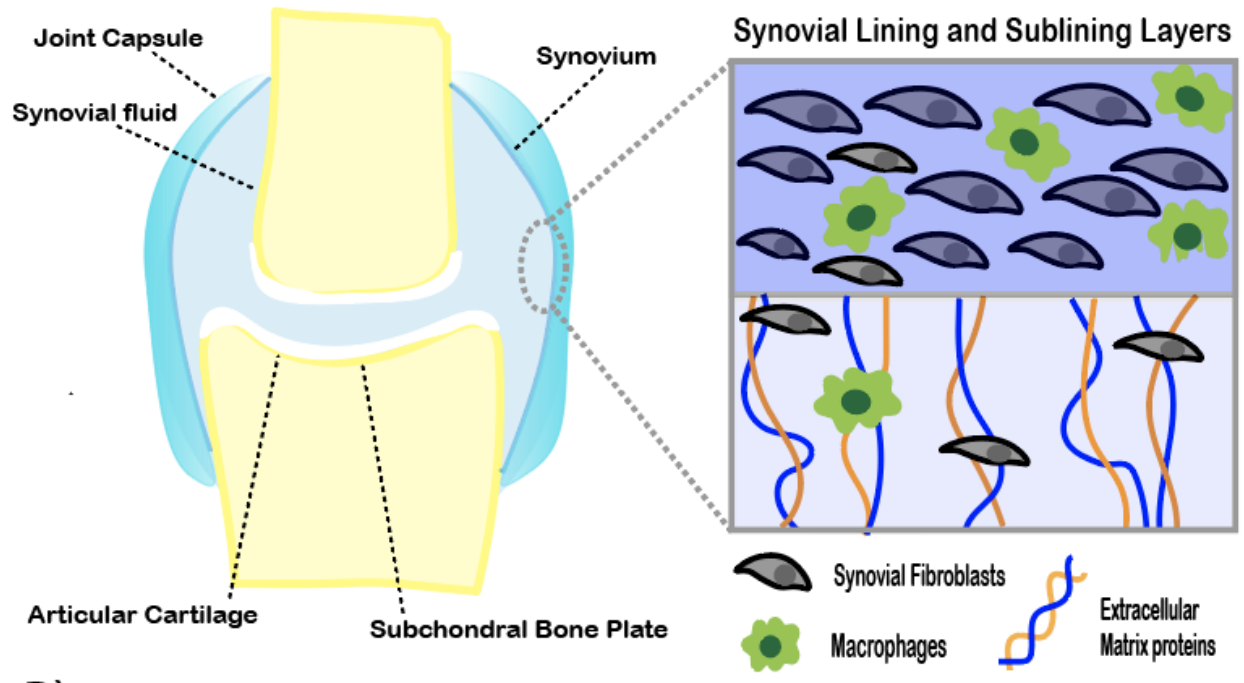

B)

\section{Rheumatoid Arthritis Joint}

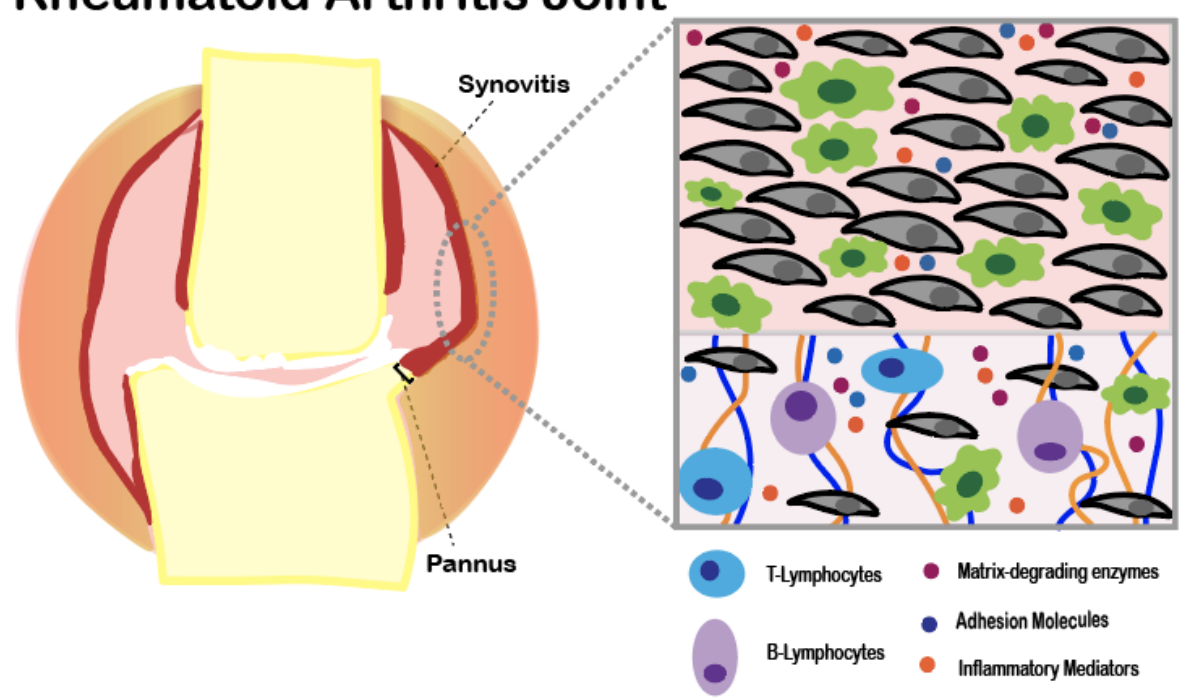

Figure 1-1. Synovium of the Joint in Health Versus Rheumatoid Arthritis (A) Healthy joints maintain a joint capsule with a 2-3 cell layer of synovial lining and lesser densely pack sublining comprised of macrophages and synovial fibroblasts, a specialized cell adapted to secrete lubricating molecules. (B) In Rheumatoid arthritis, pathological synovial fibroblast hypertrophy causes masses of 'Pannus' to form with pathological secretory phenotype that participates in chronic inflammation and causes the break down of joint cartilage and bone.

Adapted with permission. Filer, A. (2013). "The fibroblast as a therapeutic target in rheumatoid arthritis". In Current Opinion in Pharmacology. 13(3): 413-419.

https://doi.org/10.1016/j.coph.2013.02.006 (6). 
stiffening $(6,7)$. Non-steroidal anti-inflammatory drugs (NSAIDs) and corticosteroids are routinely used to temporarily control the inflammation induced by RA. The long-term approach used to prevent joint damage and other adverse systemic effects are immunomodulatory or immunosuppressant therapies identified as disease-modifying antirheumatic drugs (DMARDs) $(6,12)$.

The DMARD treatment options are categorized as synthetic or 'conventional' and biologic or 'targeted' DMARDs (6). All DMARDs work similarly by targeting molecules or cells that participate in the autoimmune response to slow disease progression and alleviate symptoms. Conventional/synthetic DMARDs have been in use for the longest and robustly target the immune system. However, some conventional/synthetic DMARDs are poorly characterized. For example, hydroxychloroquine has been used for decades as a first-line conventional DMARD, but the precise mechanism of action is unknown (12). Additionally, some individuals have pre-existing conditions that disqualify this robust targeting as a therapeutic. More recently discovered, biologic or targeted DMARDs are specific to a cell or molecule. For example, anti-TNF drugs are biologic DMARDs that specifically target the proinflammatory cytokine TNF to inhibit its interactions at a specific point in the inflammatory pathway. The use of a single biologic/targeted DMARD or combination therapy of DMARDs has transformed patient outcomes for those with poor response to conventional DMARDs. Indeed, the advent of novel DMARDs and the introduction of early, aggressive therapeutic strategies have transformed RA patient prognosis. The most successful clinical approach is to aggressively target the disease early in disease onset, using anti-inflammatory drugs concomitantly with DMARDs to alleviate symptoms and prophylactically prevent any further joint damage $(6,12,17)$.

Unfortunately, DMARDs cannot completely suppress structural damage $(12,17)$. While the purpose of corticosteroids use is to provide more timely relief during flare-ups, the corticosteroids cannot protect against joint damage and can have negative repercussions including bone density loss (18). Additionally, there are no existing drugs to target pain and swelling directly at the site of inflammation. Furthermore, concomitant use of conventional DMARD, methotrexate, along with anti-inflammatory NSAIDs increases the risk of serious adverse events such as renal failure (19). Some subsets of patients find that their arthritic symptoms are refractory to pharmacological treatment or consist of individuals who are not appropriate candidates for the available pharmaceuticals $(6,9,12)$. A systematic review reported that patients are willing to take risks as great as sudden death and cancer to fight the pain and disability caused by RA (16). Together, DMARDs maintain problems such as the risk of infections, cost, and uncontrolled and toxic effects $(12-15,19,20)$. Those diagnosed with RA maintain a significant unmet medical need despite the recent significant therapeutic advances. 


\section{Synovial Fibroblasts in the Pathology of Rheumatoid Arthritis}

The previous notion that faults immune cells as largely or solely responsible for the destructive nature of the disease is the basis for the current DMARDs. The existing DMARDs aim only to repress the autoimmune response upstream of joint destruction. Though the pathogenesis of RA remains elusive, the loss of tolerance to systemic autoimmune responses is a large component of manifestation in the joint. This is dependent on the hyperplastic synovium and its participation in inflammatory positive feedback loops $(6,9,11)$. Indeed, hallmarks of RA are defined as inflammation, abnormal cellular and humoral responses, and synovial hyperplasia (11). The healthy synovium comprises a thin layer of equal parts synovial fibroblasts (SFs) and macrophages and acts as a protective barrier $(9,23-25)$. SFs secrete the lubricating component hyaluronic acid which allows for ease of movement by making the synovial fluid viscous (25). Synovial fluid absorbs shock, reduces friction between joints, and allows for the transport of nutrients and waste (2). The inflamed synovium undergoes many changes that promote progressive destruction of RA disease activity as stimulation by inflammatory cytokines and chemokines cascades cause joint swelling, pain, and eventually loss of function $(9,11)$. It was previously poorly understood how the inflamed synovial lining initiates and promotes joint destruction. Now, the concept has become a topic of interest for potential novel, targeted RA therapeutics $(12,24)$.

First, the inflamed synovium is infiltrated by immune cells and molecules from systemic circulation. The recruitment of the inflammatory cells to the joint increases proinflammatory cytokine production $(6,24,25)$. These processes (summarized in Figure 1-1) result in osteoclast infiltration and transformation of synovium into "tumor-like" phenotypes with the capacity to degrade cartilage and bone (24, 25, 28). RA 'activated' SFs evade apoptosis and develop a hyperproliferative phenotype. The synovial lining near the articular borders forms a tumor-like mass of tissue called 'pannus' comprised of the activated SFs and osteoclasts. This process enables the invasion of the adjacent cartilage and bone (24). Osteoclasts located at the pannus-bone interface and subchondral bone are responsible for focal bone loss, but this bone loss is mediated by SFs and inflammatory cells (25). SFs utilize pathological endocrine and inflammatory capabilities to pull new blood vessels to the affected joint and coordinate chronic inflammation with other cells $(23,25,27,28)$. This causes pain and swelling in the joints. As synovitis progresses without treatment, joint fluid space narrows. Mature cases of RA illustrate this can lead to the fusing of the two connecting bones together, rendering the joint immovable (2).

In many ways, SFs imitate cancer cells (28). The SFs use the newly acquired abilities to secrete molecules that promote hypersensitivity in neurons, pathological angiogenesis in the synovium, and a chronic inflammatory environment. Specifically, RA activated SFs upregulate adhesion molecules and secrete proinflammatory molecules and matrix-degrading enzymes which contribute to cartilage destruction. This yields the capacity for SF and inflammatory cell infiltration into the extracellular matrix of the synovium (23-25). Their ability to communicate with local neurons, immune cells, and epithelial cells creates positive feedback loops that increase inflammation, pain, and 
angiogenesis to the inflamed site. Additionally, a recent finding that SFs can migrate and spread RA to unaffected joints further implicates the SFs in RA disease activity (21).

The DMARD therapies target the immune system, which is described as the passive response of chronic inflammation. Thus, no existing DMARD therapy directly impacts the aggressive response where SFs are directly implicated. The finding of SFs as pathogenic propagators creates an opportunity to target the inflamed joint directly to reduce inflammation, prevent joint degradation, reduce angiogenesis, block cell migration, and, cumulatively, reduce the pain associated with these processes. There are proteins in activated SFs under epigenetic regulation that are associated with the invasiveness of SF disease phenotype and regulation of disease severity. For instance, the Transient Receptor Potential (TRP) Channels family has become very relevant to RA activated SFs during the last decade $(69,123,128,129$ 149, 152) (Table 1-1). For example, rheumatology researchers have followed cancer efforts closely to better understand tactics for targeting RA. SFs are cancer-like in their proliferative, secretory, and invasive properties. There are several TRPV, TRPC, and TRPM channels associated with the enhancement of pro-proliferative properties in transformed cells (31). This makes select TRP channels uniquely expressed in these cells exciting therapeutic candidates.

\section{TRP Channel Involvement in Rheumatoid Arthritis}

TRP channels are essential for many physiological processes and are implicated in many diseases and cancers (29-36). Hence, TRP channels are considered excellent candidates for therapeutics. TRP channel involvement in RA is becoming better understood and is exhibited in several mechanisms of the disease. Much of the early RA research implicating TRP channels documents how their nociception is modulated in sensory neurons. Since then, their involvement has been implicated in non-neuronal cell types including immune cells and stromal cells at the RA joint. More recently, TRP channel implication in the cancer-like RA activated SFs. Because of the recent evidence that builds a case for SFs involved in chronic inflammation, disease-related pain, and disease progression, SFs make great candidates for TRP channel targeting. Recent work implicates several TRP channel members in SF proliferation, invasiveness, cell migration that spreads RA to unaffected joints, and more $(93,141,149,160)$. There is an increasing amount of evidence of ways in which targeting TRP channels in SFs could modulate RA disease.

Kochukov et al first reported functional expression of TRP channels in primary culture human SFs and postulated a critical role for TRP channels in the adaptation of SF pathological phenotype (56). Another group reported distinct stretch-sensitive calcium influx in SFs and observed other TRP channels functional in SFs from patients and rodent models (59). Later studies demonstrated the expression of several of the TRP channels including TRPA1, TRPV1, TRPV2, TRPV4, TRPM3, TRPM7, and TRPM8 in SFs (57, $58,64,149,152)$. Evidence of differences in expression of TRP channels in healthy versus malignant cells suggests the SFs also retain a unique expression profile $(34,36$, 
Table 1-1. Discovery of TRP Channel Presence and Activity in Rheumatoid Arthritis

\begin{tabular}{|c|c|c|c|c|}
\hline Channel & Cell Line & Expression & Function & Reference \\
\hline \multirow[t]{2}{*}{ TRPA1 } & $\begin{array}{l}\text { SW982 human } \\
\text { synovial } \\
\text { fibroblasts }\end{array}$ & mRNA detected & $\begin{array}{l}\text { temperature/agonist } \\
\text { induced calcium } \\
\text { intake }\end{array}$ & $\begin{array}{c}\text { Kochukov } \\
2006\end{array}$ \\
\hline & $\begin{array}{l}\text { Primary human } \\
\text { synovial } \\
\text { fibroblasts (RA } \\
+ \text { control) }\end{array}$ & $\begin{array}{l}\text { hypoxia-induced } \\
\text { seven-fold increase } \\
\text { in mRNA (in RA } \\
\text { and Control) }\end{array}$ & & $\begin{array}{l}\text { Del Rey } \\
2010\end{array}$ \\
\hline \multirow[t]{2}{*}{ TRPV1 } & $\begin{array}{l}\text { SW982 human } \\
\text { synovial } \\
\text { fibroblasts }\end{array}$ & mRNA detected & $\begin{array}{l}\text { temperature/agonist } \\
\text { induced calcium } \\
\text { intake }\end{array}$ & $\begin{array}{c}\text { Kochukov } \\
2006\end{array}$ \\
\hline & $\begin{array}{l}\text { Primary human } \\
\text { synovial } \\
\text { fibroblasts (RA } \\
+ \text { Control) }\end{array}$ & $\begin{array}{l}\text { Three-fold increase } \\
\text { in mRNA versus } \\
\text { control }\end{array}$ & $\begin{array}{l}\text { (capsaicin) agonist } \\
\text { induced calcium } \\
\text { intake, agonist } \\
\text { induced mediation of } \\
\text { production of RA- } \\
\text { related cytokine }\end{array}$ & $\begin{array}{l}\text { Engler } \\
2007\end{array}$ \\
\hline \multirow[t]{3}{*}{ TRPV2 } & $\begin{array}{l}\text { SW982 human } \\
\text { synovial } \\
\text { fibroblasts }\end{array}$ & $\begin{array}{l}\text { TNF-induced two- } \\
\text { fold increase in } \\
\text { mRNA, increased } \\
\text { protein }(8 \mathrm{hr} .)\end{array}$ & $\begin{array}{l}\text { cytokine-induced } \\
\text { sensitization to } \\
\text { agonist }\end{array}$ & $\begin{array}{c}\text { Kochukov } \\
2009\end{array}$ \\
\hline & $\begin{array}{l}\text { PIA rat model } \\
\text { synovial } \\
\text { fibroblasts }\end{array}$ & $\begin{array}{l}\text { just under two-fold } \\
\text { increase mRNA in } \\
\text { highly invasive SFs }\end{array}$ & & $\begin{array}{l}\text { Laragoine } \\
2008\end{array}$ \\
\hline & $\begin{array}{l}\text { PIA rat model, } \\
\text { KRN mice } \\
\text { model, CIA } \\
\text { mouse model, } \\
\text { and primary } \\
\text { human (RA) } \\
\text { synovial } \\
\text { fibroblasts }\end{array}$ & & $\begin{array}{l}\text { chemical agonist } \\
\text { induced calcium } \\
\text { intake, agonist } \\
\text { induced reduction of } \\
\text { cytokines and MMP } \\
\text { production }\end{array}$ & $\begin{array}{l}\text { Laragoine } \\
2015\end{array}$ \\
\hline \multirow[t]{2}{*}{ TRPV4 } & $\begin{array}{l}\text { SW982 human } \\
\text { synovial } \\
\text { fibroblasts }\end{array}$ & mRNA detected & $\begin{array}{l}\text { temperature/agonist } \\
\text { induced calcium } \\
\text { intake }\end{array}$ & $\begin{array}{c}\text { Kochukov } \\
2006\end{array}$ \\
\hline & $\begin{array}{l}\text { MH7A human } \\
\text { synovial } \\
\text { fibroblasts and } \\
\text { primary human } \\
\text { synovial } \\
\text { fibroblasts }\end{array}$ & $\begin{array}{l}\text { mRNA detected, } \\
\text { similar levels to } \\
\text { non-RA samples }\end{array}$ & $\begin{array}{l}\text { hypotonic stimulation } \\
\text { and chemical agonist } \\
\text { induced calcium } \\
\text { intake; agonist } \\
\text { induced mediation of } \\
\text { cytokine production }\end{array}$ & Itoh 2009 \\
\hline
\end{tabular}


Table 1 1. Continued

\begin{tabular}{|c|c|c|c|c|}
\hline Channel & Cell Line & Expression & Function & Reference \\
\hline \multirow[b]{2}{*}{ TRPM3 } & $\begin{array}{l}\text { SW982 human } \\
\text { synovial } \\
\text { fibroblasts }\end{array}$ & mRNA detected & $\begin{array}{l}\text { temperature/agonist } \\
\text { induced calcium } \\
\text { intake }\end{array}$ & $\begin{array}{c}\text { Kochukov } \\
2006\end{array}$ \\
\hline & $\begin{array}{l}\text { Primary human } \\
\text { synovial } \\
\text { fibroblasts (RA } \\
+ \text { control) }\end{array}$ & $\begin{array}{l}\text { hypoxia-induced } \\
\text { seven-fold increase } \\
\text { in mRNA (in RA } \\
\text { and Control) }\end{array}$ & & $\begin{array}{l}\text { Del Rey } \\
2010\end{array}$ \\
\hline TRPM7 & $\begin{array}{l}\text { CFA rat model } \\
\text { synovial } \\
\text { fibroblasts }\end{array}$ & mRNA detected & $\begin{array}{l}\text { temperature/agonist } \\
\text { induced calcium } \\
\text { intake }\end{array}$ & $\begin{array}{c}\text { Kochukov } \\
2006\end{array}$ \\
\hline \multirow[t]{2}{*}{ TRPM8 } & $\begin{array}{l}\text { SW982 human } \\
\text { synovial } \\
\text { fibroblasts }\end{array}$ & $\begin{array}{l}\text { Three-fold increase } \\
\text { in mRNA versus } \\
\text { control }\end{array}$ & $\begin{array}{l}\text { (capsaicin) agonist } \\
\text { induced calcium } \\
\text { intake, agonist } \\
\text { induced mediation of } \\
\text { production of RA- } \\
\text { related cytokine }\end{array}$ & $\begin{array}{l}\text { Engler } \\
2007\end{array}$ \\
\hline & $\begin{array}{l}\text { CIA rat model } \\
\text { synovial } \\
\text { fibroblasts }\end{array}$ & $\begin{array}{l}\text { TNF-induced two- } \\
\text { fold increase in } \\
\text { mRNA, increased } \\
\text { protein }(8 \mathrm{hr} .)\end{array}$ & $\begin{array}{l}\text { cytokine-induced } \\
\text { sensitization to } \\
\text { agonist }\end{array}$ & $\begin{array}{c}\text { Kochukov } \\
2009\end{array}$ \\
\hline \multirow[t]{2}{*}{ TRPC1 } & $\begin{array}{l}\text { Primary human } \\
\text { synovial } \\
\text { fibroblasts (RA } \\
+ \text { control) }\end{array}$ & $\begin{array}{l}\text { just under two-fold } \\
\text { increase mRNA in } \\
\text { highly invasive SFs }\end{array}$ & & $\begin{array}{l}\text { Laragoine } \\
2008\end{array}$ \\
\hline & $\begin{array}{l}\text { CFA mouse } \\
\text { model synovial } \\
\text { fibroblasts }\end{array}$ & & $\begin{array}{l}\text { chemical agonist } \\
\text { induced calcium } \\
\text { intake, agonist } \\
\text { induced reduction of } \\
\text { cytokines and MMP } \\
\text { production }\end{array}$ & $\begin{array}{l}\text { Laragoine } \\
2015\end{array}$ \\
\hline \multirow[t]{2}{*}{ TRPC5 } & $\begin{array}{l}\text { Primary human } \\
\text { synovial } \\
\text { fibroblasts (RA } \\
+ \text { control) }\end{array}$ & mRNA detected & $\begin{array}{l}\text { temperature/agonist } \\
\text { induced calcium } \\
\text { intake }\end{array}$ & $\begin{array}{l}\text { Kochukov } \\
2006\end{array}$ \\
\hline & $\begin{array}{l}\text { CFA mouse } \\
\text { model, primary } \\
\text { human synovial } \\
\text { fibroblasts }\end{array}$ & $\begin{array}{l}\text { mRNA detected, } \\
\text { similar levels to } \\
\text { non-RA samples }\end{array}$ & $\begin{array}{l}\text { hypotonic stimulation } \\
\text { and chemical agonist } \\
\text { induced calcium } \\
\text { intake; agonist } \\
\text { induced mediation of } \\
\text { cytokine production }\end{array}$ & Itoh 2009 \\
\hline
\end{tabular}


43, 107, 157-159). Indeed, various reports indicate TRP channels are differentially expressed in invasive RA SFs (Table 1-1). Research over the past decade supports the involvement of a few select TRP channels in SF disease activity. For my thesis, I reviewed the involvement of select TRP channels in RA SFs and proposed strategies for further investigating their therapeutic potential. 


\section{CHAPTER 2. TRP CHANNELS AS THERAPEUTIC CANDIDATES FOR RHEUMATOID ARTHRITIS}

\section{TRP Channel Family Characterization}

TRP channels belong to a superfamily of 28 cation channels with diverse physiological functions and cellular distributions. The TRP family is divided into subfamilies based on structural homology: A (ankyrin), C (canonical), M (melastatin), V (vanilloid), P (polycystin), and ML (mucolipin) (Figure 2-1). Each member's subunit composition has varying degrees of similarity and allows for many of the members to form hetero-oligomers with each other $(29,32)$. TRP channels are nonselective cation channels that, upon activation, can increase intracellular concentrations of cations such as calcium, sodium, and magnesium, though they are mostly known for calcium homeostasis $(29,30)$. Because expression of these channels mediates ion homeostasis, TRP channels are biological sensors important to many roles such as apoptosis, cell proliferation, and migration. The channels play roles in many physiological processes such as insulin secretion and vascular tone regulation; hence TRP channel expression changes could cause several channelopathies (30-33).

These channels are polymodal because some members of the family are activated by physical (e.g., heat, cold, pressure) and chemical (e.g., protons, toxins, bioactive lipids) stimuli (30). As a classic example, the small molecule capsaicin found in chili peppers activates TRPV1 to induce nociceptive responses which elicit heat sensation. In addition to their direct involvement in disease, their sensitization downstream of other membrane proteins (like $\mathrm{G}$ protein-coupled receptors) and other signaling molecules plays roles in chronic inflammation such as hyperalgesia $(30,32)$. Abnormal calcium homeostasis, oxidative stress, ER stress, mitochondrial dysfunction are processes linked to the RA disease progression for which TRP channels are also implicated.

\section{TRP Channel Candidates}

\section{TRPA1}

TRPA1 is the lone member of the subfamily ankyrin. TRPA1 is a calciumpermeable, nonselective cation channel that was first cloned from human fetal lung fibroblasts. Exogenous agonists for TRPA1 are allyl isothiocyanate, allicin, and cinnamaldehyde which are constituent active ingredients of mustard oil or wasabi, garlic, and cinnamon, respectively $(37,39)$. TRPA 1 can also be activated by cold temperature $(30,38)$. Endogenous agonists for TRPA1 are long-chain polyunsaturated fatty acids as well as certain lipid mediators and reactive oxygen species (ROS) that are observed in the chronic inflammatory environment of the arthritic joint $(52,61,65)$. TRPA1 has been studied for its physiological roles in airway sensory neurons and gut motility as well as in pathophysiological roles such as pain and inflammation $(31,42,43)$. 


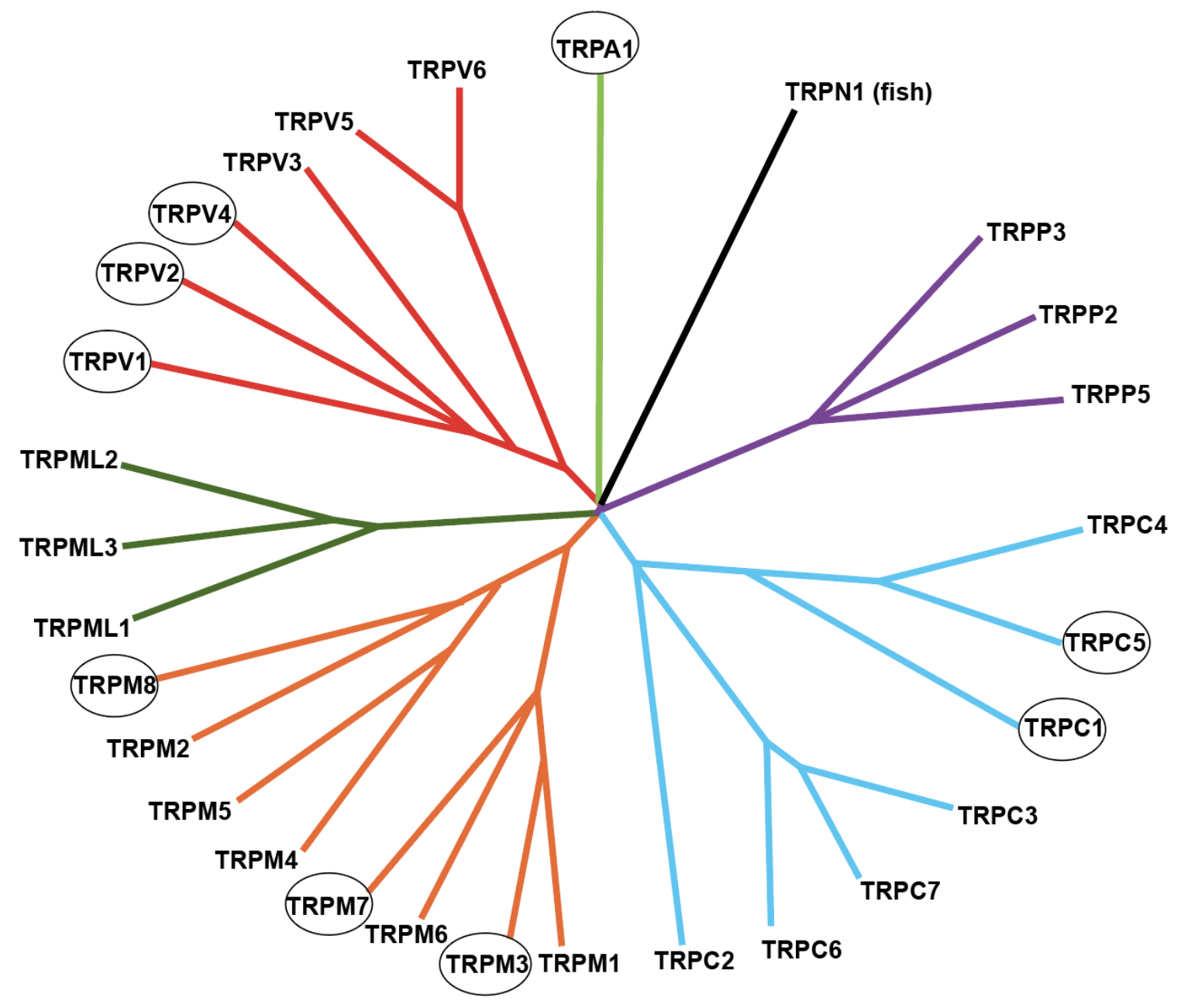

Figure 2-1. TRP Channel Phylogenetic Tree

Adapted with permission. Nilius, B., \& Owsianik, G. (2011). "The transient receptor potential family of ion channels". Genome Biology. 12(3), 218.

https://doi.org/10.1186/gb-2011-12-3-218 
Several animal models exist to probe the various mechanisms in RA (44) and have been used to probe both TRPA1 and TRPV1 by genetic knockout models or pharmacological inhibition. TRPA1 importance in arthritic pain and disease progression has mainly been studied with respect to sensory neurons (45-49). However, there is a measurable complexity in the overall contribution of TRPA1 to RA. Initially, the effect of TRPA1 genetic ablation and pharmacological inhibition in rodent models were investigated by several groups to measure sensitivity to pain and inflammation. Several groups that studied TRPA1 pharmacological antagonist or deletion observed TRPA1dependent pronounced proinflammatory or pronociceptive effects. These groups observed the presence of TRPA1 contributed to inflammatory hyperalgesia, edema, and joint degradation (45, 47-50). However, Batai and collaborators recently reported they observed the opposite effect (46). They demonstrated a protective role of TRPA1 with analgesic and anti-inflammatory properties. By using both knockout and pharmacological stimulation, they found sulfides, which can activate TRPA1 receptors (50), reverse some of the negative effects of disease progression. The group stipulated that TRPA-mediated alleviation of prior pronociceptive and proinflammatory symptoms in the humanized RA mouse model may be due to the release of neurotransmitters, like somatostatin, involved in inflammation (51). They proposed that the TRPA1-involved mechanisms studied are more complex than originally described (46).

Indeed, one example is that there are discrepancies among mouse and rat models for human RA. For example, tolerance for genetic deletion is variable among animal models of RA. Thus, this factor must be taken into account when measuring TRP channel dependency on disease parameters. The adverse effects as a function of genetic deletion intolerance could hinder accurate measurements that illustrate TRP channel dependency on specific RA disease mechanisms across RA animal models (46). Additionally, various groups have described variable expression profiles among RA animal models. Importantly, many of these the studies focused on the effect of TRPA1 ablation in sensory neuron only by using local injection techniques. However, it is now better understood that TRPA1 is upregulated in the RA disease setting in many cell types including SFs. Thus, this factor should be accounted in future studies that aim to delineate how to best target SFs.

In respect to the RA joint, TRPA1 is expressed in nociceptive neuronal cells, immune cells, epithelial cells, chondrocytes, and SFs, thus their contribution to pain and inflammation is potentially spread across several cell types (52-56). Kochukov and collaborators investigated TRP channel involvement beyond neuronal cells to understand their roles in arthritic inflammation and observed functional expression of TRPA1, TRPV1, TRPV4, and TRPM8 in SW982 human primary SFs cell line (a cell culture model for RA) (56). The same group later found a major proinflammatory cytokine in RA, tumor necrosis factor (TNF), to upregulate TRPV1 and TRPV4, but not TRPA1 and TRPM8 (58). However, a hypoxic environment, common to the RA joint synovium (67), induced transcriptional changes in SFs from RA patients. Del Rey et al reported TRPA1 is among the top 15 most upregulated proteins (64). Because activated SFs behave like cancer cells in many ways, it is relevant that stimulation of TRPA1 increases the apoptotic effect of hypoxia in a human glioblastoma cell line (65). TRPA1 also mediates 
inflammatory and invasive properties in the hypoxic environment of lung cancer cells (66).

Interestingly, Hatano et al. demonstrated that important proinflammatory mediators in RA, including TNF and interleukin-1 $\alpha$ ) (IL-1 $\alpha$ ), induced TRPA1 gene expression and downstream activation of the transcription factor hypoxia-inducible factor-1 $\alpha)(\mathrm{HIF}-1 \alpha)$. In RA backgrounds, HIF1- $\alpha$ accumulation is observed, so their findings demonstrated the accumulated transcription factor can enhance TRPA1 expression. This effect observed also suppressed secretion of proinflammatory cytokines interleukin-6 (IL-6) and interleukin-8 (IL-8), which induce intracellular signaling cascades that give rise to further inflammatory cytokine production. This mechanism studied links relevant inflammatory mediators to ion channel expression. It also demonstrates a TRPA1-mediated anti-inflammatory feedback mechanism in RA (63).

In addition, Lowin et al later also demonstrated that TNF- $\alpha$ induced upregulation and sensitization of TRPA1. The sensitization allowed for a lower concentration of agonist to activate TRPA1. This resulted in reduced viability of SFs cells. The healthy tissues had no significant change in viability, thus this antiproliferative effect on SFs was dependent on the inflammatory conditions. They also observed a reduction in cytokine and ROS production by TRPA1 activation (68). ROS are known activators of TRPA1, and multiple reports have demonstrated that ROS levels are elevated as a result of the hypoxic, proinflammatory environment present in RA. $(60,61)$. Thus, ROS can participate in a feedback loop because TRPA1 is activated by ROS and exhibits increased expression following ROS-mediated activation (61).

Other mechanisms have been explored as well. After Richardson and collaborators initially determined that the synovial endocannabinoid system is altered in RA, Lowin and colleagues investigated the influence of these naturally occurring compounds on disease state inflammation in respect to SFs (69). The endocannabinoid system indeed exerted an anti-inflammatory effect on the joint by reducing the inflammatory mediators produced by SFs. Further, the effects were dependent on the activation of TRPV1 and TRPA1. The endocannabinoids modulated TRPA1 and TRPV1 activity in SFs which correlated with downregulated proinflammatory cytokines IL-6 and IL-8 as well as matrix metalloproteinase-3 (MMP-3). MMP-3 served as an additional marker due to the abundant production of matrix-degrading proteins such as MMP-3 by SFs and their contribution to joint erosion (62). The study further revealed that the effects of the three $\mathrm{N}$-acylethanolamines used were blocked by an antagonist of TRPA1, illustrating these anti-inflammatory processes as TRP channel-dependent.

TRPA1 is an upregulated membrane protein in RA SFs with a supported role in RA. The building evidence suggests activated SFs proliferative and secretory abilities can be regulated by TRPA1-mediated mechanisms. Suppression of proliferation and secretion of proinflammatory molecules by TRPA1 should be further investigated to evaluate the candidacy of TRPA1 for pharmacological manipulation in clinical settings. Strikingly, the DMARD auranofin, which acts by inhibiting redox enzymes to suppress the inflammation in RA, is also a potent agonist of TRPA1 $(70,71)$. Because animal model 
studies seem to not have completely elucidated potential for TRPA1 activation, TRPA1 activity in SFs should be further studied in animal models of human RA. Potentially, investigation in a cell-specific knockout in a rodent model with similar expression profiles to human RA could delineate the contribution of SFs from the rest.

\section{TRPV1}

TRPV1 and TRPA1 are two of the most well-studied TRP channels. They are polymodal and show co-expression in various cell types and have both been implicated together in a host of diseases. Furthermore, the activity of TRPA1 is regulated by TRPV1 (72). The activity of both is modulated by membrane phospholipids $(29,30)$. TRPV1 is activated by heat, voltage, and chemical agonists such as vanilloids, endocannabinoid lipids, and protons. TRPV1 is expressed broadly throughout the body. TRPV1 is well known as the receptor for capsaicin (the "hot" component of chili peppers) and is also activated by ROS (30). Many molecules exist to probe mechanisms that involve the activation or blockade of TRPV1. $(32,79)$.

TRPV1 was first identified in sensory neurons and many studies have since sought to delineate TRPV1 role in pain sensation (30). TRPV1 has been extensively studied for its role in neurogenic inflammation and pain in RA animal models, mostly in respect to sensory neuron contribution. Some groups find genetic knockout or inhibition of TRPV1 to decrease hyperalgesia, edema, and joint degradation $(76,77,88,89,90)$, although there are groups that found no significance $(73,78)$. However, TRPV1 displays desensitization after activation, and the following studies focused on determining how this property might contribute to the nociceptive and inflammatory function of TRPV1. Some groups believe the stimulation of TRPV1 to be a promising therapeutic strategy to desensitize or degrade nociceptive afferents that innervate the inflamed joint $(74,79)$. Because these sensory cells attribute to perceived pain as well as secrete neuropeptides that aggravate inflammation, the effect of desensitization could have a global effect on disease progression (79-84). Moreover, the capsaicin-mediated desensitization of TRPV1-sensitive sensory afferents is what brought about the use of capsaicin as a topical analgesic (91).

In certain cancer cell lines, TRPV1 is pro-proliferative and both agonists and antagonists can trigger anti-proliferative mechanisms (35). Indeed, there is complexity surrounding TRPV1 involvement in RA. One group observed that in a RA mouse model, TRPV-expressing sensory nerves aggravate mechanical hyperalgesia in the mature phases of RA but play anti-inflammatory roles early in disease progression. The study finds that this protective mechanism could be in part by the release of the protective neuropeptide, somatostatin (75). Because of the complexity in TRPV1 activity, further investigation should be conducted to understand desensitization as a strategy for a RA therapeutic.

Moreover, the inflamed joint is maintained by many cell types, thus TRPV1 involvement is not isolated to neurons, though many of the rodent model studies have 
focused on neuronal contribution. TRPV1 is expressed in many different cell types such as sensory neurons, chondrocytes, and SFs (93-95). Thus, the ensemble of signaling pathways between cells that drive RA pathology has not yet been elucidated. Indeed, there is a suggested interplay happening between the synovial lining and sensory nerves that innervate it. A co-culture study revealed SFs from rat model of human RA influence the expression of pain-related receptors in dorsal root ganglion (DRG) neurons. Significant upregulation of TRPV1 in SFs from inflamed joints, but not normal joints, bolster activated SF activity and the impact the SFs have on pain sensation controlled by these neurons. Their results obtained from arthritic animals showed direct contact between sensory neurons and SFs resulted in upregulation of TRPV1 in the sensory neurons as well (86). The activation of TRPV1 causes the release of proinflammatory neuropeptides, substance $\mathrm{P}$ and calcitonin related peptide, from sensory neurons which elicit neurogenic inflammation in the joint. Incubation of these neuropeptides with capsaicin increases the production of the proinflammatory cytokines IL-6 and IL-8 in vitro, suggesting a cooperative mechanism for disease progression by SFs involving TRPV1 (92). The neuro-immune interactions impact the way future drugs may target SFs, and this study indicates RA-related pain is not solely dependent on sensory neurons in the joint. Further, desensitization of both cell types by TRPA1 agonist could have a compounding effect.

TRPV1 is the one of first of the family to be reported as functionally expressed in SFs from patients with RA, and thus has been more thoroughly studied (85). RA patients' joint synovial fluid is typically at a pH below 7.0 (99). Under this logic, Hu et al investigated TRPV1 activity in SFs isolated from a rat model of human RA under acidic conditions. They demonstrated elevated ROS, mitochondrial depolarization, and reduced cell viability upon TRPV1 activation by capsaicin, $\mathrm{pH} 5.5$ solution, and synergism of the two (93). However, Hu and collaborators later studied TRPV1 activation at moderately acidic $\mathrm{pH}$ 6.8, to represent RA pathological conditions and did not find the activity they reported before (100). Potentially, they observe this discrepancy is because calcium flux is tightly controlled by other proteins as well as TRPV1 at the pathophysiological pH observed in RA patients and prevent TRPV1 from its potent response originally seen at pH 5.5.

Indeed, evidence that implicates TRPV1 in the activity of RA SFs is convoluted. On top of TRPV1 activity in other cells, there are several possible RA mechanisms involving TRPV1 in SFs include proliferation, cell migration, and secretion of cytokines and other disease-promoting molecules. Indeed, studies show TRPV1 in both SF cell lines and RA patient-derived SF primary cultures, stimulation by capsaicin induces secretion of proinflammatory molecules (56-59). TRPV1 activation is also implicated in ROS generation in SFs. TRPV1 is activated by ROS and is upregulated following ROSmediated stimulation, thus ROS can engage in positive feedback $(87,93)$. Additionally, SFs secrete less hyaluronic acid in the early stages of RA (96). In supplement to hyaluronic acid's lubricating quality in synovial fluid and chondroprotective effects, previous studies show suppression of matrix metalloproteinases by hyaluronic acid in SF from RA patients $(96,97,101)$. Indeed, Caires et al. observed that hyaluronic acid effective in reducing pain by inhibiting TRPV1 activation (98). TRPV1 expression in SFs 
also indicates TRPV1 may also be a mediator of the production and secretion of hyaluronic acid.

Taken together with TRPV1 functional expression in SFs and contribution to the secretion of proinflammatory molecules, TRPV1 may further implicate SFs in RA hyperalgesia TRPV1 has many functions in RA disease activity and much of the evidence, like TRPA1, is involved. Because TRPV1 is one of the more thoroughly studied TRP channels, and many molecules exist to modulate TRPV1 activity, TRPV1 desensitization is a feasible strategy that could prove insightful in future animal model experimentation with SF-specific knockout models.

\section{TRPV2}

TRPV2 is present in SFs, but, like the other channels, is not as well studied in RA as TRPA1 and TRPV1. TRPV2 appears through many studies to be important to a variety of osmosensory functions $(30,105,120,121)$. TRPV2 has been implicated in cancer cell migration (108) and is expressed in immune-related tissues and cells (29, 117-119). It is heat-activated like TRPV1 albeit at a higher temperature threshold, thus TRPV2 has not been implicated in the heat-evoked pain $(30,32)$. Thus, the role of TRPV2 in physiology is more cryptic than TRPV1. In a recent mouse model knockout study, TRPV2 wildtype mice demonstrated no significant differences in thermal nociception. Further, a double knockout with TRPV1 showed similar results to single knockout of TRPV1 alone, illustrating that TRPV1 is the greater nociceptor of the two. However, ablation of TRPV2 featured overall health disparities such as reduced weight (106).

TRPV2 role in human disease has been much more elusive, which may be due in part to the limited set of molecules that can selectively probe TRPV2 in the past (108112). However, there is evidence that TRPV2 is expressed in the central nervous system and sensory neurons absent of TRPV1 and is activated downstream of the proinflammatory mediator, nitric oxide (114-116). In two chronic inflammatory diseases of the gastrointestinal tract, ulcerative colitis and Crohn's Disease, TRPV2 expression is also inversely correlated with disease activity and is speculated to decrease the severity of disease state inflammation (113).

Laragoine et al detected a unique expression profile in highly invasive SFs from rat models of human RA that included genes implicated in cancer-related phenotypes. Interestingly, TRPV2 expression was also increased almost two-fold by initial microarray analysis and validated at over four-fold mRNA by quantitative PCR. They used novel TRPV2 agonists to test its function using O1821, a synthetic cannabinoid that selectively stimulates TRPV2, the group confirmed TRPV2 function and further tested its role in SF invasion. O1821 reduced invasion in dose-dependent manner without toxicity, highlighting TRPV2 as an effective target. Additionally, TRPV2 with agonist reduced cytokine and matrix-degrading protein levels. Further, disease severity was reduced in vivo using a human RA mouse model. A library screening derived from O1821 allowed the identification of a novel, more potent agonist, LER13, which further reduced SF 
invasion in cells and mice model and reduced arthritis severity and inflammation in the mouse model. $(122,123)$. This example of TRP channel work in SFs provides a template for future studies in other promising TRP channels and not only implicates TRP channel involvement but identifies a novel selective agonist of TRPV2 which is potent in vivo. TRPV2 activation as a regulator of disease severity in RA goes beyond the scope of therapeutic potential for RA, but for a broad spectrum of diseases and cancers. Like TRPV1 and TRPA1, TRPV2, among other TRP channels, is expressed in both neurons and SFs. TRPV2 is a promising target with protective role in RA that should be further studied in SF-specific knockout studies as well.

\section{TRPV4}

TRPV4 is expressed in many organs such as kidney, heart, and liver and is activated by a wide number of stimuli including multiple endogenous substances, hypotonic cell swelling, shear stress, and heat (24). TRPV4 was initially described as an osmoreceptor for activation by hypotonic stimuli $(29,30)$. TRPV4 mutation is linked to several disorders, including neurodegenerative and bone growth disorders, because of the broad distribution of expression from the nervous system to osteoblasts and osteoclasts $(29,33)$. This channel a polymodal ionotropic receptor that can be activated by low $\mathrm{pH}$ and phorbol derivatives (30). TRPV4 activation causes increased intracellular calcium concentrations and cytokines in the intestine. Several studies support a role for TRPV4 in chronic inflammatory diseases such as inflammatory bowel disease. Elevated expression of TRPV4 is observed in the intestinal tissue of patients with ulcerative colitis and Chron's disease (126). In ulcerative colitis animal models, TRPV4 activation causes inflammation, and its inhibition can alleviate inflammation (125-127). In many types of cells, TRPV4 activity increases the production of ROS and nitric oxide. TRPV4 has been primarily implicated in osteoarthritis, and it is expressed in neurons, chondrocytes, and SFs of the joint. Interleukin-17 (IL-17), which has a known role in the pathogenesis of RA, upregulates the expression of TRPV4 receptors and intensifies mechanical hyperalgesia (128).

Itoh and colleagues found evidence of TRPV4 as a functional regulator of calcium in human SFs. Though the expression of TRPV4 in SFs from patients with and without RA was similar at mRNA and protein level, activation of TRPV4 in RA patient cells elicited a reduction in chemokine production. They demonstrated both potent TRPV4 agonist $4 \alpha$ PDD and hypotonic stress induce calcium response via TRPV4 activation and propose TRPV4 is an environmental sensor activated by cell-swelling in synovial fluid, mechanical stress by joint movement, and lipid metabolites produced under inflammation in joint (124). This concept was investigated further in 2017; Hu et al utilized in vitro techniques to determine the exact involvement of TRPV4 in the RA inflammatory environment. They observed hypotonic solution on SFs triggered a stress response including an increase in intracellular calcium, production of ROS, release of ATP. Hypotonic stress additionally induced cell proliferation which was abolished in a calcium-free buffer and weakened by a nonselective mechanosensitive channel blocker, 
gadolinium chloride (128). TRPV4 demonstrates a proinflammatory role in SFs that could be counteracted with an antagonist to reduce RA progression promoted by SFs.

\section{TRPC5}

TRPC5 is expressed in multiple tissues including the central nervous system, first described as an important regulator of brain development, but has also been implicated in important roles in carcinogenesis $(29,32)$. TRPC5 associates with TRPC1 to form heteromeric cation channels, and recent evidence suggests that TRPC5 and TRPC1TRPC5 complexes are functionally expressed in human RA SFs (129). Recently, Xu and collaborators reported the expression of the two TRPC channels localized together in SFs from RA patient biopsies (130). Thioredoxin is a redox protein used as a biomarker for its presence in significantly elevated extracellular concentrations in the RA joint. Interestingly, the group found thioredoxin to activate both TRPC5 and the TRPC5TRPC1 complexes (130-133). The reduced form thioredoxin can break disulfide bridges to activate the channels. The in vitro study further illustrates thioredoxin secretion and extracellular activity is a protective mechanism that inhibits metalloproteinase release from SFs. Further, the effect is reduced in the presence of an anti-TRPC5 antibody or relevant cysteine mutants of TRPC5, demonstrating TRPC channel-dependence.

Nitric oxide is also an endogenous regulator of cysteine residues (130). Nitric oxide plays a central role in many physiological processes, but its production is elevated in the chronic inflammatory environment of the RA joint (134-136). Many cell types including SFs in this environment are capable of generating elevated nitric oxide. Nitric oxide mediates functions in synovial inflammation, including cytokine production, and signal transduction, but the findings do not clearly suggest the elevated levels worsen disease outcomes (133). This may be in part due to its ability to activate TRPC5 along with other functionally expressed TRP channels in SFs. In vivo, suppression of TRPC5 activity via genetic deletion or pharmacological inhibition, results in exacerbated joint inflammation and pain sensitivity in both murine models of human RA and RA patients (133).

Alawi et al later demonstrated in a mouse model of RA that TRPC5 knockout increases inflammation and secondary hyperalgesia. Genetic ablation of TRPC1 and TRPC5 increases SF matrix metalloproteinase secretion, which is largely responsible for tissue remodeling in the RA joint (130). These findings together demonstrate lack of TRPC5 exacerbates arthritic symptoms, thus further investigation may find agonists increase anti-inflammatory functions of this channel. However, better pharmacological tools need to be developed to selectively probe TRPC5 and protective mechanisms in vivo $(129,130)$. 


\section{TRPC1}

TRPC1 is the first recognized mammalian TRP channel, and its function is better understood when in complexes with other canonical subfamily members (30). TRPC5 and TRPC1 can both be activated by $G$ protein-coupled receptors (32). TRPC1 plays a role in vascular tone regulation and cell migration (137-141). TRPC1 expression is reportedly correlated with proliferation in human breast cancer epithelial cells and is implicated in distinct roles depending on the stage of a particular cancer $(35,36)$. TRPC1 is not as upregulated as TRPC5 in activated SFs, but it forms the hetero-complex with TRPC5 that mediates extracellular concentrations of the integral redox protein, thioredoxin. Interestingly, TRPC1 is also reported as a mediator of SF cell migration (141). TRPC1 ablation in SFs from a mouse model of human RA reduced translocation by almost half in vitro. They also observed TRPC 1 deficiency also decreases sensitivity to mechanical stimulation, though the exact mechanism of this outcome is unknown (141). Because RA SFs rely on local migration to remodel the RA joint and long-distance migration to spread to unaffected joints, targeting TRPC1-dependent cell migration could be a novel strategy for these hyperplastic cells in RA. Although TRPC members' involvement in RA is less developed, there is a clear implication of TRPC5 in protective mechanisms. However, future strategies for may better be suited for inhibition due to its implication in cell migration, a key feature of the SF pathogenic phenotype.

\section{TRPM3}

TRPM3 is not as strongly characterized as other TRP channels, but its presence has been studied in the brain and kidney. It is expressed broadly and acts as a sensor for steroid hormones $(29,32,142-144)$. TRPM3 is calcium permeable and increases activity downstream of hypotonic stimuli (32). It has been established as a nociceptor for acute heat evoked pain (145). Recently, Vandewauw and collaborators report a triad of TRPM3, TRPV1, and TRPA1 is vital for heat responsiveness in based on evidence in cells and an animal model. TRPM3 is upregulated in inflamed DRG neurons and, in particular, co-expressed with TRPV1 and TRPA1. Evidence from a triple knockout in mice provides that at least one of the three TRP channels must be functional for this particular nociception (146). Interestingly, inflammation induced in the hind paw induced upregulation of the same three TRP channels, and inhibition of TRPM3 weakened the nociception of TRPV1 and TRPA1 in the inflamed but not healthy tissue $(146,147)$. A 2010 study revealed TRPM3 as a top hit for downregulation induced by hypoxia in SFs from RA patients (64).

The finding of functional TRPM3 expression in human RA SFs came later than other TRP channels, although it is expressed heterogeneously throughout the synovial tissue (149). From previous reports, pregnenolone sulfate, a neurosteroid with excitatory effects in the brain, activates TRPM3 in beta cells and is coupled to insulin secretion (148). Importantly, stimulation of TRPM3 in SFs via extracellular pregnenolone sulfate can activate TRPM3. This activation mechanism is negatively coupled to the secretion of hyaluronic acid (149). Though hyaluronic acid has a protective role initially in RA, 
elevated hyaluronic acid in mature cases of RA is correlated with joint destruction (150, 151). Accumulation of hyaluronic acid and its degradation products promotes SF mobility, adhesion, and angiogenesis, processes that serve the proinflammatory feedback loop. With respect to hyaluronic acid levels, TRPV1 may be a more effective target in the early stage of RA, but TRPM 3 targeting could be a solution for more mature cases of RA. Further studies are required to determine whether TRPM3 targeting is a viable strategy for RA wherein the molecular basis for the therapeutic benefit of pregnenolone may be discovered.

\section{TRPM7}

TRPM7 is known for its kinase domain fused to its structure, though the enzymatic function is poorly understood (32). TRPM7 is ubiquitously expressed and is known for its role in magnesium homeostasis and reabsorption in the kidney and intestine $(29,30)$. A metabolic-sensing role has been proposed for its sensitivity to intracellular Mg-ATP concentration (32). More structural data exists for TRPM7 than TRPM3 (166). Mutations in TRPM7 can result in neurodegenerative disorders (33). TRPM7 is significantly upregulated in human atrial fibroblasts from patients with atrial fibrillation (153). Along with TRPC1, TRPM7 and TRPM8 are overexpressed in human breast cancer epithelial cells which correlate with their proliferative properties (36). Previous reports indicate TRPM7 participates in several other cancers, and TRPM7 and TRPM8 are implicated in the control of motility (35). Cong-hua et al demonstrated the expression of TRPM7 in neutrophils from patients with RA and hypothesized a TRPM7 activation is a key step in calcium mobilization associated with invasiveness of human neutrophils in RA (153).

TRPM7 implication was observed later than other TRP channel members involved in pathological properties of RA activated SFs. Yu et al observed TRPM7 channels may decrease fibroblast proliferation and differentiation as studied in lung fibroblasts (155). Thereafter, Li et al explored the role of TRPM7 in SFs (155). TRPM7 is indeed functionally expressed in SFs derived from a rat model of human RA, and suppression of TRPM7 increased ER stress and induced apoptosis in SFs (156). TRPM7 characterization in RA is underdeveloped, but future study of TRPM7 inhibition by antagonist may yield a favorable strategy for attenuating SF proliferative properties.

\section{TRPM8}

TRPM8 exhibits low sequence homology to other subfamily members, though its structural data is the most advanced of the three mentioned $(30,166)$. Like TRPA1, TRPM8 is activated by cold temperature and cooling mimetic compounds such as icillin (29-31). TRPM7 and TRPM8 also appear to be stimulated by polar lipids (30). TRPM8 is broadly distributed across many tissues and cell types including vascular smooth muscle cells and trigeminal ganglia neurons. TRPM8 plays a known role in pain and temperature sensation within sensory neurons and is upregulated in certain cancer cells $(29,32)$. 
TRPM8 is implicated in some cancers and overexpression has been observed in pancreatic adenocarcinomas (157-159). Khalil and colleagues proposed the involvement of TRPM8 in macrophage function in colitis.

TRPM8 has not been thoroughly studied in the context of activated SF, but aforementioned group noted its involvement in cancer cells and inflammatory diseases. These hints to similar implications in activated SFs which are cancer-like and proinflammatory. For instance, a recent study reported TRPM8 inhibition during the Tcell activation process leads to altered phenotype and reduced proliferation without detrimental effects. Thus, TRPM8 may be a safer target for controlling cell proliferation. Indeed, Zhu and colleagues used TRPM8 agonist, menthol, to demonstrate TRPM8mediated calcium entry elicits apoptosis in SFs from RA animal model (160). Apoptosis assays confirmed cell death was via the apoptotic pathway, which is the preferred and tidy form of cell death wherein the cell does not leak any toxic internal substances. Though TRPM8 is not heavily implicated in SF disease activity, evidence of the apoptotic effect through TRPM8 activation warrants further investigation of menthol or other TRPM8 agonists on RA activated SFs. This may reveal a protective role for TRPM8 to control SF proliferation. 


\section{CHAPTER 3. CONCLUSION}

\section{Overview of TRP Channel Contribution to RA Synovial Fibroblast Activity}

The recent growth of data that supports roles for TRP channel implication in RA activated SFs further strengthens the case against these channels in RA pathogenesis, pain, and disease progression. Many preclinical techniques and pharmacological tools exist to probe the mechanisms for which some of these TRP channels may be involved. While TRP Channels such as TRPA1 and TRPV1 have been widely implicated in RA disease-specific processes, their best targeting strategies are not yet clear. Conversely, TRP Channels such as TRPV2, TRPV4, TRPC5, TRPC1, TRPM3, TRPM7, and TRPM8 are not all clearly implicated in the SF-dependent disease activity, but recent studies build attractive strategies for the TRP channels potential as therapeutic targets for RA SFs. These channels require more functional expression studies in animals and humans in disease versus health to understand their overall contribution. Some channels have previously been implicated in both protective and pathogenic in SFs which warrants future investigation. For example, both TRPV1 and TRPM3, which have been implicated in the regulation of SF hyaluronic secretion, have also been implicated in increased nociception in inflamed tissue (146). Other channels may simply be attractive for their upregulation in respect to the cell cycle due to their control of calcium homeostasis (31). Alone, the ability to control cell proliferation by initiating apoptosis of SFs in RA could significantly hinder SF ability to participate in their disease propagating roles. Altogether, further probing of TRP channels in SF disease activity could yield better understandings of their pathogenic functions and successful therapeutic strategies that control the pathogenic functions.

The TRP channels included in this review highlight a few recently identified key features that contribute to SF pathological phenotype. There are many existing endogenous and exogenous agonists and antagonists for the TRP channel family thus make the study of their implication in disease easier to investigate. With the recent advances in structural knowledge, the design of potent small molecules should not be too high a barrier and conceive feasibility for drug development (165-167). Several potential stimulation strategies could come from TRP channel structure-based drug design initiatives (166-168). Overall, the recent studies add to an emerging picture of TRP channel function in the RA joint and the potential for TRP channel targeting with the added benefit of lacking unwanted effects of current therapies that provide RA sufferers both quick and long-lasting relief. In sum, based on my readings, promising future strategies to further investigate these TRP channels as RA therapeutics that target SFs are: activation of TRPA1, TRPV1, TRPV2, TRPC5, TRPM3, TRPM8 and inhibition of TRV4, TRPC1, and TRPM7 should be tested further for mitigation and potentially prevention of inflammation and pain associated with joint degeneration as well as the progression of RA (Table 3-1). 
Table 3-1. Proposed Actions to Target TRP Channels Candidacy to Ameliorate Rheumatoid Arthritis Symptoms

\begin{tabular}{|c|c|c|c|c|}
\hline \multirow[b]{2}{*}{$\begin{array}{c}\text { TRP } \\
\text { Channel }\end{array}$} & \multicolumn{4}{|c|}{ In RA-Activated Synovial Fibroblasts } \\
\hline & $\begin{array}{l}\text { Expression } \\
\text { Profile }\end{array}$ & Implication & $\begin{array}{l}\text { Associated Pathophysiological } \\
\text { Feature(s) }\end{array}$ & $\begin{array}{l}\text { Action to } \\
\text { Suppress } \\
\text { Pathological } \\
\text { Feature(s) }\end{array}$ \\
\hline TRPV1 & upregulated & pathogenic & $\begin{array}{l}\text { cell proliferation and secretion } \\
\text { of proinflammatory molecules }\end{array}$ & $\begin{array}{c}\text { desensitization by } \\
\text { agonist }\end{array}$ \\
\hline TRPV4 & $\begin{array}{l}\text { similar to } \\
\text { health }\end{array}$ & pathogenic & $\begin{array}{l}\text { cell proliferation and ROS } \\
\text { production }\end{array}$ & $\begin{array}{l}\text { inhibition by } \\
\text { antagonist }\end{array}$ \\
\hline TRPC1 & $*$ & pathogenic & $\begin{array}{l}\text { cell migration and secretion of } \\
\text { proinflammatory molecules and } \\
\text { matrix degrading enzymes }\end{array}$ & $\begin{array}{l}\text { inhibition by } \\
\text { antagonist }\end{array}$ \\
\hline TRPM7 & upregulated & pathogenic & $\begin{array}{l}\text { cell proliferation and ROS } \\
\text { production }\end{array}$ & $\begin{array}{l}\text { inhibition by } \\
\text { antagonist }\end{array}$ \\
\hline TRPA1 & upregulated & protective & $\begin{array}{l}\text { cell proliferation and secretion } \\
\text { of proinflammatory molecules }\end{array}$ & $\begin{array}{l}\text { activation by } \\
\text { agonist }\end{array}$ \\
\hline TRPV2 & upregulated & protective & $\begin{array}{l}\text { cell migration and secretion of } \\
\text { proinflammatory molecules and } \\
\text { matrix degrading enzymes }\end{array}$ & $\begin{array}{l}\text { activation by } \\
\text { agonist }\end{array}$ \\
\hline TRPC5 & $*$ & protective & $\begin{array}{l}\text { secretion of proinflammatory } \\
\text { molecules and matrix degrading } \\
\text { enzymes }\end{array}$ & $\begin{array}{l}\text { activation by } \\
\text { agonist }\end{array}$ \\
\hline TRPM3 & $*$ & protective & $\begin{array}{l}\text { secretion of proinflammatory } \\
\text { hyaluronic acid }\end{array}$ & $\begin{array}{l}\text { activation by } \\
\text { agonist }\end{array}$ \\
\hline TRPM8 & $*$ & protective & $\begin{array}{l}\text { cell proliferation via apoptosis } \\
\text { initiation }\end{array}$ & $\begin{array}{l}\text { activation by } \\
\text { agonist }\end{array}$ \\
\hline
\end{tabular}

Note: * Further studies are needed to compare expression of rheumatoid patient or animal model to the respective controls 


\section{Perspective and Future Directions}

Arthritis is a debilitating condition that leads to painful degradation of the joint and bone. With the US population's projected increase in average lifespan, RA prevalence will continue to grow. The increase in new therapeutic options over the last decade still leaves patients to choose the tradeoff of risk for benefit. For those with RA, impaired bone health, immunity, and overall quality of life are just a few of the reasons targeted therapies are a necessity. As the number of cases of RA grows and the average years since diagnosis grows, the momentum behind drug development for RA has not kept the same momentum. SF-targeted agents could have the potential to be used concomitantly or replace current therapies by avoiding the effect on adaptive immune response entirely and targeting joint degeneration and arthritic pain at the source. The process of discovering more targeted therapies for RA is involved and will take consideration of the interplay between the disease mechanisms.

Since the development of conventional therapeutics, the quality of life for RA sufferers has increased dramatically, but not without risk. Rheumatoid arthritis therapeutic approaches lack direct targeting of inflamed joint, and investigation of novel therapeutic targets could lend hope to unexplored opportunities proposed to drug RA pathogenesis and progression directly. Over the past decade, increasing evidence towards the SF as the culprit for the pathological changes in RA joint anatomy and proinflammatory environment at disease onset has set efforts to find molecular targets in motion. Recent advances in understanding the biology of SFs including their regulation of innate immune responses and activation of intracellular signaling mechanisms that control their behavior provide novel insights into disease mechanisms.

SFs, the leading cells in joint erosion, create the inflammatory environment in the synovium, attract more immune cells to the damage to propagate RA. Evidence for TRP channels as potential RA therapeutic target is fragmented for some more than others. However, there is promise in probing TRP channels to control hyperplasia and depress secretion and mobility of SFs in the RA joint. While the persistent, proinflammatory phenotype of SFs is one of the main contributors to disease progression, no specific therapy targeting this cell type is currently available. Evidence of the ways in which TRP channels modulate secretion, mediate cell migration, and even induce cell death in RA activated SFs has set a motion that allows for new targeted therapies to be discovered (Figure 3-1).

There is an abundance of evidence for TRP family involvement in RA, but because many of these TRP channels are broadly expressed, it is important to note their involvement in RA by other cell types. The cells that SFs communicate with to exacerbate joint damage is a layer of complexity that needs to be explored further in respect to TRP channel involvement. Further, TRP channels must be studied with the consideration of the complexity in their activation. TRPV1 ablation was shown to ameliorate RA symptoms in animal models. However, desensitization by using agonists alleviated RA symptoms better than blocking TRPV1 activity. This concept should be taken into account in the study of other TRP channels as candidates. Additionally, some 


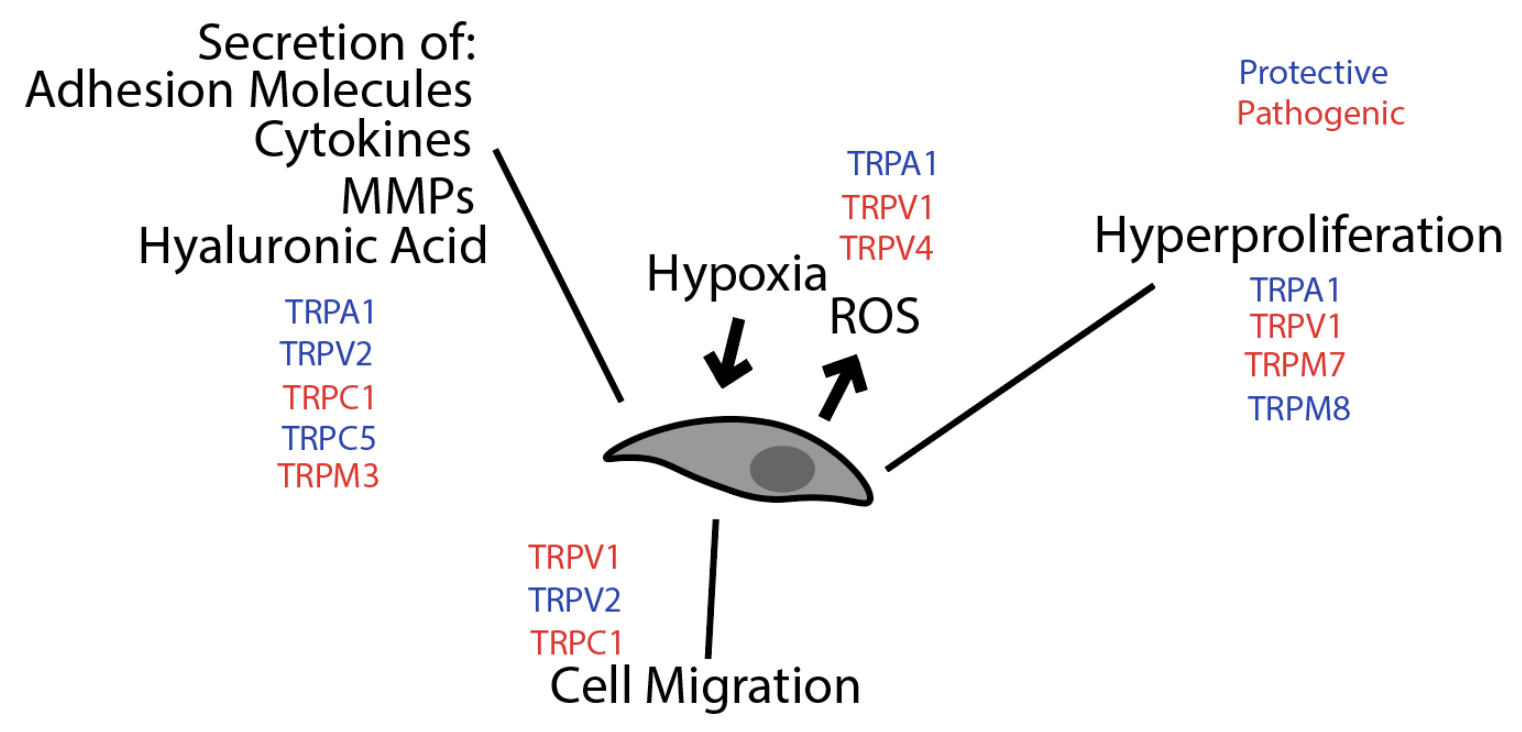

Figure 3-1. Activated Synovial Fibroblast Mechanisms Involving TRP Channels TRP Channels have protective (blue) or pathogenic (red) implications on activated SFs which may overlap several mechanisms the SFs utilize to create the inflammatory environment of the joint and propagate RA. 
members are known to have more than one role in RA. The TRP channels involved in pain processing such as TRPV1, TRPA1, and TRPM3 show high levels of expression in sensory neurons innervating inflamed tissue of arthritic joint (146).

In addition to inflammation related to neurogenic pathways, there are other mechanisms that activated SFs signaling can stimulate. Angiogenesis, the process in which new blood vessels grow from existing ones to meet increased oxygen and nutrient demand, is physiologically required in development and wound healing. However, it can be pathologically associated with many chronic inflammatory diseases, autoimmune diseases, and cancer $(163,164)$. In the inflamed environment of the joint, epithelial cells interact with stromal cells to determine which factors are secreted and to what extent. The increase in blood vessels to the synovium enables the infiltration of immune cells to the joint, which promotes a state of chronic inflammation (163). Smani et al reviewed the role of transient receptor potential (TRP) channels expressed by endothelial cells in growth factor-induced angiogenesis. TRP channels are activated by pro-angiogenic factors resulting in the rise of intracellular signaling pathways that promote angiogenesis (165).

TRPM8 and TRPA1 are implicated in the enhanced motility and metastases formation in certain lung cancer cells (35). Further, it is intriguing that a recent study reported TRPV1 is upregulated in TMJ (temporomandibular joint) synovium by an estrogen metabolite in a rat model of temporomandibular disorders because RA is two to three times more prevalent in women (102). More recently, dopamine, which modulates TRPV1 in DRG neurons, is implicated in the migration ability of SFs from RA patients $(103,104)$. In addition to other studies that implicated TRP channels in RA activated SF activities, TRPV1 shows potential for future discoveries such as the delineation of the sexual dimorphism observed in RA. Because we know the proinflammatory environment implicates TRP channels such as TNF-alpha sensitizing TRPA1, and current drugs aim upstream like the anti-TNF biologic DMARDs, looking at a downstream approach for flare-ups may prove to be more effective at alleviating pain and ameliorating disease progression. SF specific knockout models could be the key to understanding how TRP channel therapeutics behave on the joint as a whole, and further investigation of TRP channels as RA therapeutic candidates could completely alter the disease progression in the RA joint. 


\section{LIST OF REFERENCES}

1. Hunter, T. M., Boytsov, N. N., Zhang, X., Schroeder, K., Michaud, K., \& Araujo, A. B. (2017). Prevalence of rheumatoid arthritis in the United States adult population in healthcare claims databases, 2004-2014. Rheumatology international, 37(9), 1551-1557. https://doi.org/10.1007/s00296-017-3726-1

2. Ruffing, V. (n.d.) Rheumatoid Arthritis. Retrieved from: https://www.hopkinsarthritis.org/arthritis-info/rheumatoid-arthritis/

3. Mikuls, T.R. (2010). Rheumatoid arthritis incidence: What goes down must go up?. Arthritis \& Rheumatism, 62: 1565-1567. https://doi.org/10.1002/art.27432

4. Hresko, A., Lin, T. C., Solomon, D. H. (2018) Medical Care Costs Associated With Rheumatoid Arthritis in the US: A Systematic Literature Review and MetaAnalysis. Arthritis Care Res (Hoboken). 70(10):1431-1438. https://doi.org/10.1002/acr.23512

5. Barhamain, A. S., Magliah, R. F., Shaheen, M. H., Munassar, S. F., Falemban, A. M., Alshareef, M. M., \& Almoallim, H. M. (2017). The journey of rheumatoid arthritis patients: a review of reported lag times from the onset of symptoms. Open access rheumatology: research and reviews, 9, 139-150. https://doi.org/10.2147/OARRR.S138830

6. Smolen, J. S., Aletaha, D., \& McInnes, I. B. (2016). Rheumatoid arthritis. Lancet (London, England), 388(10055), 2023-2038. https://doi.org/10.1016/S0140$\underline{6736(16) 30173-8}$

7. Karami, J., Aslani, S., Jamshidi, A., Garshasbi, M., \& Mahmoudi, M. (2019). Genetic implications in the pathogenesis of rheumatoid arthritis; an updated review. Gene, 702, 8-16. https://doi.org/10.1016/j.gene.2019.03.033

8. Aslani, S., Mahmoudi, M., Karami, J., Jamshidi, A. R., Malekshahi, Z., \& Nicknam, M. H. (2016). Epigenetic alterations underlying autoimmune diseases. Autoimmunity, 49(2), 69-83. https://doi.org/10.3109/08916934.2015.1134511

9. McInnes, I.B., Schett, G. (2010). The Pathogenesis of Rheumatoid Arthritis. New England Journal of Medicine. 2011;365(23):2205-2219. https://doi.org/10.1056/NEJMra1004965

10. Carlens, C., Hergens, M.P., Grunewald, J., Ekbom, A., Eklund, A., Höglund C.O., Askling, J. (2010). Smoking, use of moist snuff, and risk of chronic inflammatory diseases. American Journal of Respiratory \& Critical Care Medicine, 181(11), 1217-1222. https://doi.org/10.1164/rccm.200909-1338OC 
11. Gay, S., Gay, R. E., \& Koopman, W. J. (1993). Molecular and cellular mechanisms of joint destruction in rheumatoid arthritis: two cellular mechanisms explain joint destruction? Annals of the Rheumatic Diseases, 52 Suppl 1, S39S47. https://doi.org/10.1136/ard.52.suppl_1.s39

12. Abbasi, M., Mousavi, M. J., Jamalzehi, S., Alimohammadi, R., Bezvan, M. H., Mohammadi, H., \& Aslani, S. (2019). Strategies toward rheumatoid arthritis therapy; the old and the new. Journal of cellular physiology, 234(7), 1001810031. https://doi.org/10.1002/jcp.27860

13. Choy, E.H., Smith, C., Doré, C.J., Scott, D.L. (2005). A meta-analysis of the efficacy and toxicity of combining disease-modifying anti-rheumatic drugs in rheumatoid arthritis based on patient withdrawal. Rheumatology (Oxford);44(11):1414-21. https://doi.org/10.1093/rheumatology/kei031

14. Donahue KE, Gartlehner G, Jonas DE, Lux LJ, Thieda P, Jonas BL, Hansen RA, Morgan LC, Lohr KN, Donahue, K. E., Gartlehner, G., Jonas, D. E., Lux, L. J., Thieda, P., Jonas, B. L., Hansen, R. A., Morgan, L. C., \& Lohr, K. N. (2008). Systematic review: comparative effectiveness and harms of disease-modifying medications for rheumatoid arthritis. Annals of Internal Medicine, 148(2), 124134. https://doi.org/10.7326/0003-4819-148-2-200801150-00192

15. Grøn, K. L., Arkema, E. V., Glintborg, B., Mehnert, F., Østergaard, M., Dreyer, L., Nørgaard, M., Krogh, N. S., Askling, J., Hetland, M. L., \& ARTIS Study Group (2019). Risk of serious infections in patients with rheumatoid arthritis treated in routine care with abatacept, rituximab and tocilizumab in Denmark and Sweden. Annals of the rheumatic diseases, 78(3), 320-327. https://doi.org/10.1136/annrheumdis-2018-214326

16. Durand, C., Eldoma, M., Marshall, D. A., Bansback, N., \& Hazlewood, G. S. (2020). Patient Preferences for Disease-modifying Antirheumatic Drug Treatment in Rheumatoid Arthritis: A Systematic Review. The Journal of rheumatology, 47(2), 176-187. https://doi.org/10.3899/jrheum.181165

17. Kahlenberg, J. M., \& Fox, D. A. (2011). Advances in the medical treatment of rheumatoid arthritis. Hand clinics, 27(1), 11-20. https://doi.org/10.1016/i.hcl.2010.09.002

18. Pereira, R. M., Carvalho, J. F., \& Canalis, E. (2010). Glucocorticoid-induced osteoporosis in rheumatic diseases. Clinics (Sao Paulo, Brazil), 65(11), 11971205. https://doi.org/10.1590/s1807-59322010001100024

19. Svanström, H., Lund, M., Melbye, M., \& Pasternak, B. (2018). Concomitant use of low-dose methotrexate and NSAIDs and the risk of serious adverse events among patients with rheumatoid arthritis. Pharmacoepidemiology and drug safety, 27(8), 885-893. https://doi.org/10.1002/pds.4555 
20. Listing, J., Strangfeld, A., Kary, S., Rau, R., von Hinueber, U., Stoyanova-Scholz, M., Gromnica-Ihle, E., Antoni, C., Herzer, P., Kekow, J., Schneider, M., \& Zink, A. (2005). Infections in patients with rheumatoid arthritis treated with biologic agents. Arthritis and rheumatism, 52(11), 3403-3412.

https://doi.org/10.1002/art.21386

21. Lefèvre, S., Knedla, A., Tennie, C., Kampmann, A., Dinser, R., Tarner, I. H., Müller-Ladner, U., Neumann, E., Wunrau, C., Pap, T., Korb, A., Schnäker, E.-M., Robbins, P. D., Evans, C. H., Stürz, H., Steinmeyer, J., Gay, S., \& Schölmerich, J. (2009). Synovial fibroblasts spread rheumatoid arthritis to unaffected joints.

Nature Medicine, 15(12), 1414-1420. https://doi.org/10.1038/nm.2050

22. Karami, J., Aslani, S., Tahmasebi, M. N., Mousavi, M. J., Sharafat Vaziri, A., Jamshidi, A., Farhadi, E., \& Mahmoudi, M. (2020). Epigenetics in rheumatoid arthritis; fibroblast-like synoviocytes as an emerging paradigm in the pathogenesis of the disease. Immunology and Cell Biology, 98(3), 171-186. https://doi.org/10.1111/imcb.12311

23. Pap, T., Müller-Ladner, U., Gay, R. E., \& Gay, S. (2000). Fibroblast biology. Role of synovial fibroblasts in the pathogenesis of rheumatoid arthritis. Arthritis research, 2(5), 361-367. https://doi.org/10.1186/ar113

24. Filer A. (2013). The fibroblast as a therapeutic target in rheumatoid arthritis. Current opinion in pharmacology, 13(3), 413-419. https://doi.org/10.1016/j.coph.2013.02.006

25. Huber, L.C., Distler, O., Tarner, I., Gay, R.E., Gay, S., Pap, T. (2006) Synovial fibroblasts: key players in rheumatoid arthritis. Rheumatology (Oxford). 2006 Jun;45(6):669-75. https://doi.org/10.1093/rheumatology/kel065

26. Turner, J. D., \& Filer, A. (2015). The role of the synovial fibroblast in rheumatoid arthritis pathogenesis. Current opinion in rheumatology, 27(2), 175-182. https://doi.org/10.1097/BOR.0000000000000148

27. Zimmermann-Geller B, Köppert S, Kesel N, Hasseli R, Ullrich S, Lefèvre S, Frommer K, Gehrke T, Schönburg M, Rehart S, Schumacher U, Müller-Ladner U, Neumann E. (2019) Interactions between rheumatoid arthritis synovial fibroblast migration and endothelial cells. Immunol Cell Biol. https://doi.org/10.1111/imcb.12208

28. Laragione, T., \& Gulko, P. S. (2010). mTOR regulates the invasive properties of synovial fibroblasts in rheumatoid arthritis. Molecular medicine (Cambridge, Mass.), 16(9-10), 352-358. https://doi.org/10.2119/molmed.2010.00049 
29. Nilius, B., \& Owsianik, G. (2011). The transient receptor potential family of ion channels. Genome biology, 12(3), 218. https://doi.org/10.1186/gb-2011-12-3-218

30. Ramsey, I. S., Delling, M., \& Clapham, D. E. (2006). An Introduction to Trp Channels. Annual Review of Physiology, 68(1), 619-647. https://doi.org/10.1146/annurev.physiol.68.040204.100431

31. Smani, T., Shapovalov, G., Skryma, R., Prevarskaya, N., \& Rosado, J. A. (2015). Functional and physiopathological implications of TRP channels. Biochimica et biophysica acta, 1853(8), 1772-1782. https://doi.org/10.1016/j.bbamcr.2015.04.016

32. Clapham D. E. (2003). TRP channels as cellular sensors. Nature, 426(6966), 517524. https://doi.org/10.1038/nature02196

33. Nilius, B., \& Owsianik, G. (2010). Transient receptor potential channelopathies. Pflugers Archiv : European journal of physiology, 460(2), 437-450. https://doi.org/10.1007/s00424-010-0788-2

34. Santoni, G., Maggi, F., Morelli, M. B., Santoni, M., \& Marinelli, O. (2019). Transient Receptor Potential Cation Channels in Cancer Therapy. Medical sciences (Basel, Switzerland), 7(12), 108. https://doi.org/10.3390/medsci7120108

35. Shapovalov, G., Ritaine, A., Skryma, R., \& Prevarskaya, N. (2016). Role of TRP ion channels in cancer and tumorigenesis. Seminars in immunopathology, 38(3), 357-369. https://doi.org/10.1007/s00281-015-0525-1

36. Dhennin-Duthille, I., Gautier, M., Faouzi, M., Guilbert, A., Brevet, M., Vaudry, D., Ahidouch, A., Sevestre, H., \& Ouadid-Ahidouch, H. (2011). High expression of transient receptor potential channels in human breast cancer epithelial cells and tissues: correlation with pathological parameters. Cellular physiology and biochemistry : international journal of experimental cellular physiology, biochemistry, and pharmacology, 28(5), 813-822. https://doi.org/10.1159/000335795

37. Legrand, C., Merlini, J. M., de Senarclens-Bezençon, C., \& Michlig, S. (2020). New natural agonists of the transient receptor potential Ankyrin 1 (TRPA1) channel. Scientific reports, 10(1), 11238. https://doi.org/10.1038/s41598-020$\underline{68013-2}$

38. Story, G. M., Peier, A. M., Reeve, A. J., Eid, S. R., Mosbacher, J., Hricik, T. R., Earley, T. J., Hergarden, A. C., Andersson, D. A., Hwang, S. W., McIntyre, P., Jegla, T., Bevan, S., \& Patapoutian, A. (2003). ANKTM1, a TRP-like channel expressed in nociceptive neurons, is activated by cold temperatures. Cell, 112(6), 819-829. https://doi.org/10.1016/s0092-8674(03)00158-2 
39. Jordt, S. E., Bautista, D. M., Chuang, H. H., McKemy, D. D., Zygmunt, P. M., Högestätt, E. D., Meng, I. D., \& Julius, D. (2004). Mustard oils and cannabinoids excite sensory nerve fibres through the TRP channel ANKTM1. Nature, 427(6971), 260-265. https://doi.org/10.1038/nature02282

40. Redmond, W. J., Gu, L., Camo, M., McIntyre, P., \& Connor, M. (2014). Ligand determinants of fatty acid activation of the pronociceptive ion channel TRPA1. PeerJ, 2, e248. https://doi.org/10.7717/peerj.248

41. Bessac, B. F., Sivula, M., von Hehn, C. A., Escalera, J., Cohn, L., \& Jordt, S. E. (2008). TRPA1 is a major oxidant sensor in murine airway sensory neurons. The Journal of clinical investigation, 118(5), 1899-1910. https://doi.org/10.1172/JCI34192

42. Jordt, S. E., Bautista, D. M., Chuang, H. H., McKemy, D. D., Zygmunt, P. M., Högestätt, E. D., Meng, I. D., \& Julius, D. (2004). Mustard oils and cannabinoids excite sensory nerve fibres through the TRP channel ANKTM1. Nature, 427(6971), 260-265. https://doi.org/10.1038/nature02282

43. Stokes, A., Wakano, C., Koblan-Huberson, M., Adra, C. N., Fleig, A., \& Turner, H. (2006). TRPA1 is a substrate for de-ubiquitination by the tumor suppressor CYLD. Cellular signalling, 18(10), 1584-1594. https://doi.org/10.1016/j.cellsig.2005.12.009

44. Kannan, K., Ortmann, R. A., \& Kimpel, D. (2005). Animal models of rheumatoid arthritis and their relevance to human disease. Pathophysiology : the official journal of the International Society for Pathophysiology, 12(3), 167-181. https://doi.org/10.1016/j.pathophys.2005.07.011

45. Fernandes, E. S., Russell, F. A., Spina, D., McDougall, J. J., Graepel, R., Gentry, C., Staniland, A. A., Mountford, D. M., Keeble, J. E., Malcangio, M., Bevan, S., \& Brain, S. D. (2011). A distinct role for transient receptor potential ankyrin 1, in addition to transient receptor potential vanilloid 1 , in tumor necrosis factor $\alpha$ induced inflammatory hyperalgesia and Freund's complete adjuvant-induced monarthritis. Arthritis and rheumatism, 63(3), 819-829.

https://doi.org/10.1002/art.30150

46. Bátai, I. Z., Sár, C. P., Horváth, Á., Borbély, É., Bölcskei, K., Kemény, Á., Sándor, Z., Nemes, B., Helyes, Z., Perkecz, A., Mócsai, A., Pozsgai, G., \& Pintér, E. (2019). TRPA1 Ion Channel Determines Beneficial and Detrimental Effects of GYY4137 in Murine Serum-Transfer Arthritis. Frontiers in pharmacology, 10, 964. https://doi.org/10.3389/fphar.2019.00964

47. Horváth, Á., Tékus, V., Boros, M., Pozsgai, G., Botz, B., Borbély, É., Szolcsányi, J., Pintér, E., \& Helyes, Z. (2016). Transient receptor potential ankyrin 1 (TRPA1) receptor is involved in chronic arthritis: in vivo study using TRPA1- 
deficient mice. Arthritis research \& therapy, 18, 6 . https://doi.org/10.1186/s13075-015-0904-y

48. Garrison, S. R., \& Stucky, C. L. (2014). Contribution of transient receptor potential ankyrin 1 to chronic pain in aged mice with complete Freund's adjuvantinduced arthritis. Arthritis \& rheumatology (Hoboken, N.J.), 66(9), 2380-2390. https://doi.org/10.1002/art.38724

49. Fernandes, E. S., Russell, F. A., Alawi, K. M., Sand, C., Liang, L., Salamon, R., Bodkin, J. V., Aubdool, A. A., Arno, M., Gentry, C., Smillie, S. J., Bevan, S., Keeble, J. E., Malcangio, M., \& Brain, S. D. (2016). Environmental cold exposure increases blood flow and affects pain sensitivity in the knee joints of CFAinduced arthritic mice in a TRPA1-dependent manner. Arthritis research \& therapy, 18, 7. https://doi.org/10.1186/s13075-015-0905-x

50. Hajna, Z., Sághy, É., Payrits, M., Aubdool, A. A., Szőke, É., Pozsgai, G., Bátai, I. Z., Nagy, L., Filotás, D., Helyes, Z., Brain, S. D., \& Pintér, E. (2016). CapsaicinSensitive Sensory Nerves Mediate the Cellular and Microvascular Effects of H2S via TRPA1 Receptor Activation and Neuropeptide Release. Journal of Molecular Neuroscience : MN, 60(2), 157-170. https://doi.org/10.1007/s12031-016-0802-z

51. Pintér, E., Helyes, Z., \& Szolcsányi, J. (2006). Inhibitory effect of somatostatin on inflammation and nociception. Pharmacology \& therapeutics, 112(2), 440-456. https://doi.org/10.1016/j.pharmthera.2006.04.010

52. Brain S. D. (2011). TRPV1 and TRPA1 channels in inflammatory pain: elucidating mechanisms. Annals of the New York Academy of Sciences, 1245, 36-37. https://doi.org/10.1111/j.1749-6632.2011.06326.x

53. Zhao, J.-F., Shyue, S.-K., Kou, Y. R., Lu, T.-M., and Lee, T.-S. (2016). Transient receptor potential ankyrin 1 channel involved in atherosclerosis and macrophagefoam cell formation. Int. J. Biol. Sci. 12, 812-823. https://doi.org/10.7150/ijbs.15229

54. Pereira, I., Mendes, S. J., Pereira, D. M., Muniz, T. F., Colares, V. L., Monteiro, C. R., Martins, M. M., Grisotto, M. A., Monteiro-Neto, V., Monteiro, S. G., Calixto, J. B., Brain, S. D., \& Fernandes, E. S. (2017). Transient Receptor Potential Ankyrin 1 Channel Expression on Peripheral Blood Leukocytes from Rheumatoid Arthritic Patients and Correlation with Pain and Disability. Frontiers in pharmacology, 8, 53. https://doi.org/10.3389/fphar.2017.00053

55. Bertin, S., Aoki-Nonaka, Y., Lee, J., de Jong, P. R., Kim, P., Han, T., Yu, T., To, K., Takahashi, N., Boland, B. S., Chang, J. T., Ho, S. B., Herdman, S., Corr, M., Franco, A., Sharma, S., Dong, H., Akopian, A. N., \& Raz, E. (2017). The TRPA1 ion channel is expressed in CD4+ T cells and restrains T-cell-mediated colitis 
through inhibition of TRPV1. Gut, 66(9), 1584-1596.

https://doi.org/10.1136/gutjnl-2015-310710

56. Kochukov, M. Y., McNearney, T. A., Fu, Y., \& Westlund, K. N. (2006).

Thermosensitive TRP ion channels mediate cytosolic calcium response in human synoviocytes. American journal of physiology. Cell physiology, 291(3), C424C432. https://doi.org/10.1152/ajpcell.00553.2005

57. Sun, W., Hu, F. \& Yang, W. (2008). Heat and hyposmotic stimulation increase in $[\mathrm{Ca} 2+] \mathrm{i}$ by $\mathrm{Ca} 2+$ influx in rat synoviocytes. Chin. Sci. Bull. 53, 548-554. https://doi.org/10.1007/s11434-008-0133-8

58. Ma, F., Zhang, L., Yin, H., McNearney, T., Kochukoy, M., Ponomareva, L., Abshire, S. \& Westlund, K. (2009). Tumor necrosis factor-alpha (TNF- $\alpha$ ) enhances functional thermal and chemical responses of TRP cation channels in human synoviocytes. Molecular Pain, 5(1), 49. https://doi.org/10.1186/1744$\underline{8069-5-49}$

59. Sakamoto, Y., M.Ishijima, H., Kaneko, I., Futami, H., Kurosawa, N., Kurebayashi, N. Ichikawa, \& Arikawa-Hirasawa, E. (2010) Distinct Mechanosensitive Ca2+ Influx Mechanisms in Human Primary Synovial Fibroblasts. Journal of Orthopaedic Research 28 (7): 859-64. https://doi.org/10.1002/jor.21080

60. Laragione, T., Brenner, M., Li, W., \& Gulko, P. S. (2008). Cia5d regulates a new fibroblast-like synoviocyte invasion-associated gene expression signature. Arthritis research \& therapy, 10(4), R92. https://doi.org/10.1186/ar2476

61. Phull, A. R., Nasir, B., Haq, I. U., \& Kim, S. J. (2018). Oxidative stress, consequences and ROS mediated cellular signaling in rheumatoid arthritis. Chemico-biological interactions, 281, 121-136.

https://doi.org/10.1016/j.cbi.2017.12.024

62. Sun, S., Bay-Jensen, A. C., Karsdal, M. A., Siebuhr, A. S., Zheng, Q., Maksymowych, W. P., Christiansen, T. G., \& Henriksen, K. (2014). The active form of MMP-3 is a marker of synovial inflammation and cartilage turnover in inflammatory joint diseases. BMC musculoskeletal disorders, 15, 93. https://doi.org/10.1186/1471-2474-15-93

63. Hatano, N., Itoh, Y., Suzuki, H., Muraki, Y., Hayashi, H., Onozaki, K., Wood, I.C., Beech, D.J., Muraki, K. (2012) Hypoxia-inducible factor-1 $\alpha$ (HIF1 $\alpha$ ) switches on transient receptor potential ankyrin repeat 1 (TRPA1) gene expression via a hypoxia response element-like motif to modulate cytokine release. J Biol Chem. 2012 Sep 14;287(38):31962-72.

https://doi.org/10.1074/jbc.M112.361139 
64. Del Rey, M. J., Izquierdo, E., Usategui, A., Gonzalo, E., Blanco, F. J., Acquadro, F., \& Pablos, J. L. (2010). The transcriptional response of normal and rheumatoid arthritis synovial fibroblasts to hypoxia. Arthritis and Rheumatism, 62(12), 35843594. https://doi.org/10.1002/art.27750

65. Deveci, H. A., Akyuva, Y., Nur, G., \& Nazıroğlu, M. (2019). Alpha lipoic acid attenuates hypoxia-induced apoptosis, inflammation and mitochondrial oxidative stress via inhibition of TRPA1 channel in human glioblastoma cell line.

Biomedicine \& pharmacotherapy = Biomedecine \& pharmacotherapie, 111, 292 304. https://doi.org/10.1016/j.biopha.2018.12.077

66. Du, G. J., Li, J. H., Liu, W. J., Liu, Y. H., Zhao, B., Li, H. R., Hou, X. D., Li, H., Qi, X. X., \& Duan, Y. J. (2014). The combination of TRPM8 and TRPA1 expression causes an invasive phenotype in lung cancer. Tumour biology : the journal of the International Society for Oncodevelopmental Biology and Medicine, 35(2), 1251-1261. https://doi.org/10.1007/s13277-013-1167-3

67. Quiñonez-Flores, C. M., González-Chávez, S. A., \& Pacheco-Tena, C. (2016). Hypoxia and its implications in rheumatoid arthritis. Journal of biomedical science, 23(1), 62. https://doi.org/10.1186/s12929-016-0281-0

68. Lowin, T., Apitz, M., Straub, R.H., Anders, S. (2015) Anti-inflammatory effects of $\mathrm{N}$-acylethanolamines in rheumatoid arthritis synovial cells are mediated by TRPV1 and TRPA1 in a COX-2 dependent manner. Arthritis Research and Therapy. 17(1). https://doi.org/10.1186/s13075-015-0845-5

69. Lowin, T., Bleck, J., Schneider, M., Pongratz, G. (2018). Selective killing of proinflammatory synovial fibroblasts via activation of transient receptor potential ankyrin (TRPA1). Biochemical Pharmacology. 154:293-302. https://doi.org/10.1016/j.bcp.2018.05.015

70. Hatano, N., Suzuki, H., Muraki, Y., \& Muraki, K. (2013). Stimulation of human TRPA1 channels by clinical concentrations of the antirheumatic drug auranofin. American journal of physiology. Cell physiology, 304(4), C354-C361. https://doi.org/10.1152/ajpcell.00096.2012

71. Roder, C., \& Thomson, M. J. (2015). Auranofin: repurposing an old drug for a golden new age. Drugs in R\&D, 15(1), 13-20. https://doi.org/10.1007/s40268$\underline{015-0083-y}$

72. Fischer, M. J., Balasuriya, D., Jeggle, P., Goetze, T. A., McNaughton, P. A., Reeh, P. W., \& Edwardson, J. M. (2014). Direct evidence for functional TRPV1/TRPA1 heteromers. Pflugers Archiv : European journal of physiology, 466(12), 2229-2241. https://doi.org/10.1007/s00424-014-1497-z 
73. Cathcart, C. J., Johnston, S. A., Reynolds, L. R., Al-Nadaf, S., \& Budsberg, S. C. (2012). Efficacy of ABT-116, an antagonist of transient receptor potential vanilloid type 1 , in providing analgesia for dogs with chemically induced synovitis. American journal of veterinary research, 73(1), 19-26. https://doi.org/10.2460/ajvr.73.1.19

74. Kissin, E. Y., Freitas, C. F., \& Kissin, I. (2005). The effects of intraarticular resiniferatoxin in experimental knee-joint arthritis. Anesthesia and analgesia, 101(5), 1433-1439. https://doi.org/10.1213/01.ANE.0000180998.29890.B0

75. Borbély, É., Botz, B., Bölcskei, K., Kenyér, T., Kereskai, L., Kiss, T., Szolcsányi, J., Pintér, E., Csepregi, J. Z., Mócsai, A., \& Helyes, Z. (2015). Capsaicin-sensitive sensory nerves exert complex regulatory functions in the serum-transfer mouse model of autoimmune arthritis. Brain, behavior, and immunity, 45, 50-59. https://doi.org/10.1016/i.bbi.2014.12.012

76. Barton, N. J., McQueen, D. S., Thomson, D., Gauldie, S. D., Wilson, A. W., Salter, D. M., \& Chessell, I. P. (2006). Attenuation of experimental arthritis in TRPV1R knockout mice. Experimental and molecular pathology, 81(2), 166-170. https://doi.org/10.1016/j.yexmp.2006.04.007

77. Chen, Y., Willcockson, H. H., \& Valtschanoff, J. G. (2009). Vanilloid receptor TRPV1-mediated phosphorylation of ERK in murine adjuvant arthritis.

Osteoarthritis and cartilage, 17(2), 244-251. https://doi.org/10.1016/j.joca.2008.06.015

78. $\quad$ Ängeby Möller, K., Berge, O. G., Finn, A., Stenfors, C., \& Svensson, C. I. (2015). Using gait analysis to assess weight bearing in rats with Freund's complete adjuvant-induced monoarthritis to improve predictivity: Interfering with the cyclooxygenase and nerve growth factor pathways. European journal of pharmacology, 756, 75-84. https://doi.org/10.1016/j.ejphar.2015.02.050

79. Ahmed, M., Bjurholm, A., Srinivasan, G. R., Lundeberg, T., Theodorsson, E., Schultzberg, M., \& Kreicbergs, A. (1995). Capsaicin effects on substance P and CGRP in rat adjuvant arthritis. Regulatory peptides, 55(1), 85-102. https://doi.org/10.1016/0167-0115(94)00095-f

80. 80. Touska, F., Marsakova, L., Teisinger, J., \& Vlachova, V. (2011). A "cute" desensitization of TRPV1. Current pharmaceutical biotechnology, 12(1), $122-$ 129. https://doi.org/10.2174/138920111793937826

81. Cho, W. G., \& Valtschanoff, J. G. (2008). Vanilloid receptor TRPV1-positive sensory afferents in the mouse ankle and knee joints. Brain research, 1219, 59-65. https://doi.org/10.1016/j.brainres.2008.04.043 
82. Levine, J. D., Clark, R., Devor, M., Helms, C., Moskowitz, M. A., \& Basbaum, A. I. (1984). Intraneuronal substance P contributes to the severity of experimental arthritis. Science (New York, N.Y.), 226(4674), 547-549.

https://doi.org/10.1126/science.6208609

83. Larsson, J., Ekblom, A., Henriksson, K., Lundeberg, T., \& Theodorsson, E. (1991). Concentration of substance P, neurokinin A, calcitonin gene-related peptide, neuropeptide $\mathrm{Y}$ and vasoactive intestinal polypeptide in synovial fluid from knee joints in patients suffering from rheumatoid arthritis. Scandinavian journal of rheumatology, 20(5), 326-335. https://doi.org/10.3109/03009749109096808

84. Ross R. A. (2003). Anandamide and vanilloid TRPV1 receptors. British journal of pharmacology, 140(5), 790-801. https://doi.org/10.1038/sj.bjp.0705467

85. Engler, A., Aeschlimann, A., Simmen, B. R., Michel, B. A., Gay, R. E., Gay, S., \& Sprott, H. (2007). Expression of transient receptor potential vanilloid 1 (TRPV1) in synovial fibroblasts from patients with osteoarthritis and rheumatoid arthritis. Biochemical and biophysical research communications, 359(4), 884888. https://doi.org/10.1016/j.bbrc.2007.05.178

86. von Banchet, G. S., Richter, J., Hückel, M., Rose, C., Bräuer, R., \& Schaible, H. G. (2007). Fibroblast-like synovial cells from normal and inflamed knee joints differently affect the expression of pain-related receptors in sensory neurones: a co-culture study. Arthritis research \& therapy, 9(1), R6. https://doi.org/10.1186/ar2112

87. Westlund, K. N., Kochukov, M. Y., Lu, Y., \& McNearney, T. A. (2010). Impact of central and peripheral TRPV1 and ROS levels on proinflammatory mediators and nociceptive behavior. Molecular pain, 6, 46. https://doi.org/10.1186/1744$\underline{8069-6-46}$

88. Fischer, M. J., Btesh, J., \& McNaughton, P. A. (2013). Disrupting sensitization of transient receptor potential vanilloid subtype 1 inhibits inflammatory hyperalgesia. The Journal of neuroscience : the official journal of the Society for Neuroscience, 33(17), 7407-7414. https://doi.org/10.1523/JNEUROSCI.3721$\underline{12.2013}$

89. Keeble, J., Russell, F., Curtis, B., Starr, A., Pinter, E., \& Brain, S. D. (2005). Involvement of transient receptor potential vanilloid 1 in the vascular and hyperalgesic components of joint inflammation. Arthritis and rheumatism, 52(10), 3248-3256. https://doi.org/10.1002/art.21297

90. Szabó, A., Helyes, Z., Sándor, K., Bite, A., Pintér, E., Németh, J., Bánvölgyi, A., Bölcskei, K., Elekes, K., \& Szolcsányi, J. (2005). Role of transient receptor potential vanilloid 1 receptors in adjuvant-induced chronic arthritis: in vivo study 
using gene-deficient mice. The Journal of pharmacology and experimental therapeutics, 314(1), 111-119. https://doi.org/10.1124/jpet.104.082487

91. Mason, L., Moore, R. A., Derry, S., Edwards, J. E., \& McQuay, H. J. (2004). Systematic review of topical capsaicin for the treatment of chronic pain. BMJ (Clinical research ed.), 328(7446), 991. https://doi.org/10.1136/bmj.38042.506748.EE

92. Terenzi, R., Romano, E., Manetti, M., Peruzzi, F., Nacci, F., Matucci-Cerinic, M., $\&$ Guiducci, S. (2013). Neuropeptides activate TRPV1 in rheumatoid arthritis fibroblast-like synoviocytes and foster IL-6 and IL-8 production. Annals of the rheumatic diseases, 72(6), 1107-1109. https://doi.org/10.1136/annrheumdis-2012$\underline{202846}$

93. Hu, F., Sun, W., Yang, W., Zhao, X. T., \& Cui, Z. (2008) TRPV1 mediates cell death in rat synovial fibroblasts through calcium entry-dependent ROS production and mitochondrial depolarization. Biochemical and Biophysical Research Communications, 369(4), 989-993. https://doi.org/10.1016/j.bbrc.2008.02.155

94. Gavenis, K., Schumacher, C., Schneider, U., Eisfeld, J., Mollenhauer, J., \& Schmidt-Rohlfing, B. (2009). Expression of ion channels of the TRP family in articular chondrocytes from osteoarthritic patients: changes between native and in vitro propagated chondrocytes. Molecular and cellular biochemistry, 321(1-2), 135-143. https://doi.org/10.1007/s11010-008-9927-x

95. Somogyi, C. S., Matta, C., Foldvari, Z., Juhász, T., Katona, É., Takács, Á. R., Hajdú, T., Dobrosi, N., Gergely, P., \& Zákány, R. (2015). Polymodal Transient Receptor Potential Vanilloid (TRPV) Ion Channels in Chondrogenic Cells. International journal of molecular sciences, 16(8), 18412-18438. https://doi.org/10.3390/ijms160818412

96. Moreland L. W. (2003). Intra-articular hyaluronan (hyaluronic acid) and hylans for the treatment of osteoarthritis: mechanisms of action. Arthritis research \& therapy, 5(2), 54-67. https://doi.org/10.1186/ar623

97. Xing, D., Wang, B., Liu, Q., Ke, Y., Xu, Y., Li, Z., \& Lin, J. (2016). Intraarticular Hyaluronic Acid in Treating Knee Osteoarthritis: a PRISMA-Compliant Systematic Review of Overlapping Meta-analysis. Scientific reports, 6, 32790. https://doi.org/10.1038/srep32790

98. Caires, R., Luis, E., Taberner, F. J., Fernandez-Ballester, G., Ferrer-Montiel, A., Balazs, E. A., Gomis, A., Belmonte, C., \& de la Peña, E. (2015). Hyaluronan modulates TRPV1 channel opening, reducing peripheral nociceptor activity and pain. Nature Communications, 6, 8095. https://doi.org/10.1038/ncomms9095 
99. Geborek, P., Saxne, T., Pettersson, H., \& Wollheim, F. A. (1989). Synovial fluid acidosis correlates with radiological joint destruction in rheumatoid arthritis knee joints. The Journal of rheumatology, 16(4), 468-472.

100. 100. Hu, F., Yang, S., Zhao, D., Zhu, S., Wang, Y., \& Li, J. (2012). Moderate extracellular acidification inhibits capsaicin-induced cell death through regulating calcium mobilization, NF- $\mathrm{kB}$ translocation and ROS production in synoviocytes. Biochemical and biophysical research communications, 424(1), 196-200. https://doi.org/10.1016/j.bbrc.2012.06.115

101. Jiang, D., Liang, J., \& Noble, P. W. (2011). Hyaluronan as an immune regulator in human diseases. Physiological reviews, 91(1), 221-264. https://doi.org/10.1152/physrev.00052.2009

102. Wu, Y., Hao, T., Kou, X., Gan, Y., Ma, X. (2015) Synovial TRPV1 is upregulated by $17-\beta$-estradiol and involved in allodynia of inflamed temporomandibular joints in female rats. Archives of Oral Biology. 60-9 1310-1318. ISSN 0003-9969. https://doi.org/10.1016/j.archoralbio.2015.05.011.

103. van Nie, L., Salinas-Tejedor, L., Dychus, N., Fasbender, F., Hülser, M. L., Cutolo, M., Rehart, S., Neumann, E., Müller-Ladner, U., \& Capellino, S. (2020). Dopamine induces in vitro migration of synovial fibroblast from patients with rheumatoid arthritis. Scientific reports, 10(1), 11928. https://doi.org/10.1038/s41598-020-68836-z

104. Chakraborty, S., Rebecchi, M., Kaczocha, M., \& Puopolo, M. (2016). Dopamine modulation of transient receptor potential vanilloid type 1 (TRPV1) receptor in dorsal root ganglia neurons. The Journal of physiology, 594(6), 1627-1642. https://doi.org/10.1113/JP271198

105. Caterina, M. J., Rosen, T. A., Tominaga, M., Brake, A. J., \& Julius, D. (1999). A capsaicin-receptor homologue with a high threshold for noxious heat. Nature, 398(6726), 436-441. https://doi.org/10.1038/18906

106. Park, U., Vastani, N., Guan, Y., Raja, S. N., Koltzenburg, M., \& Caterina, M. J. (2011). TRP vanilloid 2 knock-out mice are susceptible to perinatal lethality but display normal thermal and mechanical nociception. The Journal of neuroscience : the official journal of the Society for Neuroscience, 31(32), 11425-11436. https://doi.org/10.1523/JNEUROSCI.1384-09.2011

107. Monet, M., Gkika, D., Lehen'kyi, V., Pourtier, A., Vanden Abeele, F., Bidaux, G., Juvin, V., Rassendren, F., Humez, S., \& Prevarsakaya, N. (2009). Lysophospholipids stimulate prostate cancer cell migration via TRPV2 channel activation. Biochimica et biophysica acta, 1793(3), 528-539. https://doi.org/10.1016/j.bbamcr.2009.01.003 
108. Vriens, J., Appendino, G., \& Nilius, B. (2009). Pharmacology of vanilloid transient receptor potential cation channels. Molecular pharmacology, 75(6), 1262-1279. https://doi.org/10.1124/mol.109.055624

109. Qin, N., Neeper, M. P., Liu, Y., Hutchinson, T. L., Lubin, M. L., \& Flores, C. M. (2008). TRPV2 is activated by cannabidiol and mediates CGRP release in cultured rat dorsal root ganglion neurons. The Journal of neuroscience : the official journal of the Society for Neuroscience, 28(24), 6231-6238. https://doi.org/10.1523/JNEUROSCI.0504-08.2008

110. De Petrocellis, L., Ligresti, A., Moriello, A. S., Allarà, M., Bisogno, T., Petrosino, S., Stott, C. G., \& Di Marzo, V. (2011). Effects of cannabinoids and cannabinoidenriched Cannabis extracts on TRP channels and endocannabinoid metabolic enzymes. British journal of pharmacology, 163(7), 1479-1494. https://doi.org/10.1111/j.1476-5381.2010.01166.x

111. Hu, H. Z., Gu, Q., Wang, C., Colton, C. K., Tang, J., Kinoshita-Kawada, M., Lee, L. Y., Wood, J. D., \& Zhu, M. X. (2004). 2-aminoethoxydiphenyl borate is a common activator of TRPV1, TRPV2, and TRPV3. The Journal of biological chemistry, 279(34), 35741-35748. https://doi.org/10.1074/jbc.M404164200

112. Ma Q. P. (2001). Vanilloid receptor homologue, VRL1, is expressed by both Aand C-fiber sensory neurons. Neuroreport, 12(17), 3693-3695. https://doi.org/10.1097/00001756-200112040-00018

113. Morita, T., Mitsuyama, K., Yamasaki, H., Mori, A., Yoshimura, T., Araki, T., Morita, M., Tsuruta, K., Yamasaki, S., Kuwaki, K., Yoshioka, S., Takedatsu, H., \& Torimura, T. (2020). Gene Expression of Transient Receptor Potential Channels in Peripheral Blood Mononuclear Cells of Inflammatory Bowel Disease Patients. Journal of clinical medicine, 9(8), 2643. https://doi.org/10.3390/jcm9082643

114. Lewinter, R. D., Skinner, K., Julius, D., \& Basbaum, A. I. (2004). Immunoreactive TRPV-2 (VRL-1), a capsaicin receptor homolog, in the spinal cord of the rat. The Journal of comparative neurology, 470(4), 400-408. https://doi.org/10.1002/cne.20024

115. Nedungadi, T. P., Dutta, M., Bathina, C. S., Caterina, M. J., \& Cunningham, J. T. (2012). Expression and distribution of TRPV2 in rat brain. Experimental neurology, 237(1), 223-237. https://doi.org/10.1016/j.expneurol.2012.06.017

116. Link, T. M., Park, U., Vonakis, B. M., Raben, D. M., Soloski, M. J., \& Caterina, M. J. (2010). TRPV2 has a pivotal role in macrophage particle binding and phagocytosis. Nature immunology, 11(3), 232-239.

https://doi.org/10.1038/ni.1842

117. Zhang D, Spielmann A, Wang L, Ding G, Huang F, Gu Q, Schwarz W. Mast-cell degranulation induced by physical stimuli involves the activation of transient- 
receptor-potential channel TRPV2. Physiol Res. 2012;61(1):113-24. https://doi.org/10.33549/physiolres.932053

118. Stokes, A. J., Shimoda, L. M., Koblan-Huberson, M., Adra, C. N., \& Turner, H. (2004). A TRPV2-PKA signaling module for transduction of physical stimuli in mast cells. The Journal of experimental medicine, 200(2), 137-147. https://doi.org/10.1084/jem.20032082

119. Saunders, C. I., Kunde, D. A., Crawford, A., \& Geraghty, D. P. (2007). Expression of transient receptor potential vanilloid 1 (TRPV1) and 2 (TRPV2) in human peripheral blood. Molecular immunology, 44(6), 1429-1435. https://doi.org/10.1016/j.molimm.2006.04.027

120. Nedungadi, T. P., Carreño, F. R., Walch, J. D., Bathina, C. S., \& Cunningham, J. T. (2012). Region-specific changes in transient receptor potential vanilloid channel expression in the vasopressin magnocellular system in hepatic cirrhosisinduced hyponatraemia. Journal of neuroendocrinology, 24(4), 642-652. https://doi.org/10.1111/j.1365-2826.2011.02273.x

121. Muraki, K., Iwata, Y., Katanosaka, Y., Ito, T., Ohya, S., Shigekawa, M., \& Imaizumi, Y. (2003). TRPV2 is a component of osmotically sensitive cation channels in murine aortic myocytes. Circulation research, 93(9), 829-838. https://doi.org/10.1161/01.RES.0000097263.10220.0C

122. Laragione, T., Cheng, K.F., Tanner, M.R., He, M., Beeton, C., Al-Abed, Y., \& Gulko, P.S. (2015). The cation channel Trpv2 is a new suppressor of arthritis severity, joint damage, and synovial fibroblast invasion. Clinical Immunology, 158(2), 183-192. https://doi.org/10.1016/j.clim.2015.04.001

123. Laragione, T., Harris, C., \& Gulko, P. S. (2019) TRPV2 suppresses Rac1 and RhoA activation and invasion in rheumatoid arthritis fibroblast-like synoviocytes. International Immunopharmacology, 70, 268-273. https://doi.org/10.1016/j.intimp.2019.02.051

124. Itoh, Y., Hatano, N., Muraki, K., Hayashi, H., Onozaki, K., \& Miyazawa, K. (2009) An environmental sensor, TRPV4 is a novel regulator of intracellular $\mathrm{Ca} 2+$ in human synoviocytes. American Journal of Physiology - Cell Physiology, 297(5), C1082-C1090. https://doi.org/10.1152/ajpcell.00204.2009

125. Mack, K., \& Fischer, M. (2017). Disrupting sensitization of TRPV4. Neuroscience, 352, 1-8. https://doi.org/10.1016/j.neuroscience.2017.03.037

126. D'Aldebert, E., Cenac, N., Rousset, P., Martin, L., Rolland, C., Chapman, K., Selves, J., Alric, L., Vinel, J. P., \& Vergnolle, N. (2011). Transient receptor potential vanilloid 4 activated inflammatory signals by intestinal epithelial cells 
and colitis in mice. Gastroenterology, 140(1), 275-285.

https://doi.org/10.1053/j.gastro.2010.09.045

127. Fichna, J., Mokrowiecka, A., Cygankiewicz, A. I., Zakrzewski, P. K., MałeckaPanas, E., Janecka, A., Krajewska, W. M., \& Storr, M. A. (2012). Transient receptor potential vanilloid 4 blockade protects against experimental colitis in mice: a new strategy for inflammatory bowel diseases treatment?.

Neurogastroenterology and motility : the official journal of the European Gastrointestinal Motility Society, 24(11), e557-e560. https://doi.org/10.1111/j.1365-2982.2012.01999.x

128. Hu, F., Hui, Z., Wei, W., Yang, J., Chen, Z., Guo, B., Xing, F., Zhang, X., Pan, L., \& Xu, J. (2017) Hypotonic stress promotes ATP release, reactive oxygen species production and cell proliferation via TRPV4 activation in rheumatoid arthritis rat synovial fibroblasts. Biochemical and Biophysical Research Communications. 486(1):108-115. https://doi.org/10.1016/j.bbrc.2017.03.008

129. Alawi, K.M., Russell, F.A., Aubdool, A.A., Srivastava, S., Baldissera, L., Thakore P., Saleque, N., Fernandes, E. S., Brain, S.D., Riffo-Vasquez, Y., \& Walsh, D.A. (2015) Transient receptor potential canonical 5 (TRPC5) protects against pain and vascular inflammation in arthritis and joint inflammation. Annals of the Rheumatic Diseases. 76(1):252-260. https://doi.org/10.1136/annrheumdis$\underline{2015-208886}$

130. Xu, S. Z., Sukumar, P., Zeng, F., Li, J., Jairaman, A., English, A., Naylor, J., Ciurtin, C., Majeed, Y., Milligan, C. J., Bahnasi, Y. M., Al-Shawaf, E., Porter, K. E., Jiang, L. H., Emery, P., Sivaprasadarao, A., \& Beech, D. J. (2008). TRPC channel activation by extracellular thioredoxin. Nature, 451(7174), 69-72. https://doi.org/10.1038/nature06414

131. Jikimoto, T., Nishikubo, Y., Koshiba, M., Kanagawa, S., Morinobu, S., Morinobu, A., Saura, R., Mizuno, K., Kondo, S., Toyokuni, S., Nakamura, H., Yodoi, J., \& Kumagai, S. (2002). Thioredoxin as a biomarker for oxidative stress in patients with rheumatoid arthritis. Molecular immunology, 38(10), 765-772. https://doi.org/10.1016/s0161-5890(01)00113-4

132. Maurice, M. M., Nakamura, H., Gringhuis, S., Okamoto, T., Yoshida, S., Kullmann, F., Lechner, S., van der Voort, E. A., Leow, A., Versendaal, J., MullerLadner, U., Yodoi, J., Tak, P. P., Breedveld, F. C., \& Verweij, C. L. (1999).

Expression of the thioredoxin-thioredoxin reductase system in the inflamed joints of patients with rheumatoid arthritis. Arthritis and rheumatism, 42(11), 24302439. https://doi.org/10.1002/1529-0131(199911)42:11<2430::AIDANR22>3.0.CO;2-6

133. Yoshida, T., Inoue, R., Morii, T., Takahashi, N., Yamamoto, S., Hara, Y., Tominaga, M., Shimizu, S., Sato, Y., \& Mori, Y. (2006). Nitric oxide activates 
TRP channels by cysteine S-nitrosylation. Nature Chemical Biology, 2(11), 596607. https://doi.org/10.1038/nchembio821

134. Li, H., \& Wan, A. (2013). Apoptosis of rheumatoid arthritis fibroblast-like synoviocytes: possible roles of nitric oxide and the thioredoxin 1. Mediators of inflammation, 2013, 953462. https://doi.org/10.1155/2013/953462

135. Choi J. W. (2003). Nitric oxide production is increased in patients with rheumatoid arthritis but does not correlate with laboratory parameters of disease activity. Clinica chimica acta; international journal of clinical chemistry, 336(12), 83-87. https://doi.org/10.1016/s0009-8981(03)00324-3

136. Nagy, G., Koncz, A., Telarico, T., Fernandez, D., Ersek, B., Buzás, E., \& Perl, A. (2010). Central role of nitric oxide in the pathogenesis of rheumatoid arthritis and systemic lupus erythematosus. Arthritis research \& therapy, 12(3), 210. https://doi.org/10.1186/ar3045

137. Beech D. J. (2013). Characteristics of transient receptor potential canonical calcium-permeable channels and their relevance to vascular physiology and disease. Circulation journal : official journal of the Japanese Circulation Society, 77(3), 570-579. https://doi.org/10.1253/circj.cj-13-0154

138. Bergdahl, A., Gomez, M. F., Dreja, K., Xu, S. Z., Adner, M., Beech, D. J., Broman, J., Hellstrand, P., \& Swärd, K. (2003). Cholesterol depletion impairs vascular reactivity to endothelin- 1 by reducing store-operated $\mathrm{Ca} 2+$ entry dependent on TRPC1. Circulation research, 93(9), 839-847. https://doi.org/10.1161/01.RES.0000100367.45446.A3

139. Gonzalez-Cobos, J. C., \& Trebak, M. (2010). TRPC channels in smooth muscle cells. Frontiers in bioscience (Landmark edition), 15, 1023-1039. https://doi.org/10.2741/3660

140. Vennekens R. (2011). Emerging concepts for the role of TRP channels in the cardiovascular system. The Journal of physiology, 589(Pt 7), 1527-1534. https://doi.org/10.1113/jphysiol.2010.202077

141. Fabian, A., Bertrand, J., Lindemann, O., Pap, T., \& Schwab, A. (2012). Transient receptor potential canonical channel 1 impacts on mechanosignaling during cell migration. Pflugers Archiv : European journal of physiology, 464(6), 623-630. https://doi.org/10.1007/s00424-012-1169-9

142. Fonfria, E., Murdock, P. R., Cusdin, F. S., Benham, C. D., Kelsell, R. E., \& McNulty, S. (2006). Tissue distribution profiles of the human TRPM cation channel family. Journal of receptor and signal transduction research, 26(3), 159178. https://doi.org/10.1080/10799890600637506 
143. Lee, N., Chen, J., Sun, L., Wu, S., Gray, K. R., Rich, A., Huang, M., Lin, J. H., Feder, J. N., Janovitz, E. B., Levesque, P. C., \& Blanar, M. A. (2003). Expression and characterization of human transient receptor potential melastatin 3 (hTRPM3). The Journal of biological chemistry, 278(23), 20890-20897. https://doi.org/10.1074/jbc.M211232200

144. Wagner, T. F. J., Loch, S., Lambert, S., Straub, I., Mannebach, S., Mathar, I., Düfer, M., Lis, A., Flockerzi, V., Philipp, S. E., \& Oberwinkler, J. (2008). Transient receptor potential M3 channels are ionotropic steroid receptors in pancreatic beta cells. Nature Cell Biology, 10(12), 1421-1430. https://doi.org/10.1038/ncb1801

145. Vriens, J., Owsianik, G., Hofmann, T., Philipp, S. E., Stab, J., Chen, X., Benoit, M., Xue, F., Janssens, A., Kerselaers, S., Oberwinkler, J., Vennekens, R., Gudermann, T., Nilius, B., \& Voets, T. (2011). TRPM3 is a nociceptor channel involved in the detection of noxious heat. Neuron, 70(3), 482-494. https://doi.org/10.1016/j.neuron.2011.02.051

146. Vandewauw, I., De Clercq, K., Mulier, M., Held, K., Pinto, S., Van Ranst, N., Segal, A., Voet, T., Vennekens, R., Zimmermann, K., Vriens, J., \& Voets, T. (2018). A TRP channel trio mediates acute noxious heat sensing. Nature, 555(7698), 662-666. https://doi.org/10.1038/nature26137

147. Mulier, M., Van Ranst, N., Corthout, N., Munck, S., Vanden Berghe, P., Vriens, J., Voets, T., \& Moilanen, L. (2020). Upregulation of TRPM3 in nociceptors innervating inflamed tissue. eLife, 9, e61103. https://doi.org/10.7554/eLife.61103

148. Naylor, J., Li, J., Milligan, C. J., Zeng, F., Sukumar, P., Hou, B., Sedo, A., Yuldasheva, N., Majeed, Y., Beri, D., Jiang, S., Seymour, V. A., McKeown, L., Kumar, B., Harteneck, C., O'Regan, D., Wheatcroft, S. B., Kearney, M. T., Jones, C., Porter, K. E., ... Beech, D. J. (2010). Pregnenolone sulphate- and cholesterolregulated TRPM3 channels coupled to vascular smooth muscle secretion and contraction. Circulation research, 106(9), 1507-1515. https://doi.org/10.1161/CIRCRESAHA.110.219329

149. Ciurtin, C., Majeed, Y., Naylor, J., Sukumar, P., English, A. A., Emery, P., \& Beech, D. J. (2010) TRPM3 channel stimulated by pregnenolone sulphate in synovial fibroblasts and negatively coupled to hyaluronan. BMC Musculoskelet Disord 11, 111. https://doi.org/10.1186/1471-2474-11-111.

150. Roth, A., Mollenhauer, J., Wagner, A., Fuhrmann, R., Straub, A., Venbrocks, R. A., Petrow, P., Bräuer, R., Schubert, H., Ozegowski, J., Peschel, G., Müller, P. J., \& Kinne, R. W. (2005). Intra-articular injections of high-molecular-weight hyaluronic acid have biphasic effects on joint inflammation and destruction in rat antigen-induced arthritis. Arthritis research \& therapy, 7(3), R677-R686. https://doi.org/10.1186/ar1725 
151. Voelcker, V., Gebhardt, C., Averbeck, M., Saalbach, A., Wolf, V., Weih, F., Sleeman, J., Anderegg, U., \& Simon, J. (2008). Hyaluronan fragments induce cytokine and metalloprotease upregulation in human melanoma cells in part by signalling via TLR4. Experimental dermatology, 17(2), 100-107. https://doi.org/10.1111/j.1600-0625.2007.00638.x

152. Li, X., Wang, X., Wang, Y., Li, X., Huang, C., \& Li, J. (2014). Inhibition of transient receptor potential melastatin 7 (TRPM7) channel induces RA FLSs apoptosis through endoplasmic reticulum (ER) stress. Clinical rheumatology, 33(11), 1565-1574. https://doi.org/10.1007/s10067-014-2599-x

153. Du, J., Xie, J., Zhang, Z., Tsujikawa, H., Fusco, D., Silverman, D., Liang, B., \& Yue, L. (2010). TRPM7-mediated Ca2+ signals confer fibrogenesis in human atrial fibrillation. Circulation research, 106(5), 992-1003. https://doi.org/10.1161/CIRCRESAHA.109.206771

154. Wang, C. H., Rong, M. Y., Wang, L., Ren, Z., Chen, L. N., Jia, J. F., Li, X. Y., Wu, Z. B., Chen, Z. N., \& Zhu, P. (2014). CD147 up-regulates calcium-induced chemotaxis, adhesion ability and invasiveness of human neutrophils via a TRPM7-mediated mechanism. Rheumatology (Oxford, England), 53(12), 2288-2296. https://doi.org/10.1093/rheumatology/keu260

155. Yu, M., Huang, C., Huang, Y., Wu, X., Li, X., \& Li, J. (2013). Inhibition of TRPM7 channels prevents proliferation and differentiation of human lung fibroblasts. Inflammation research : official journal of the European Histamine Research Society ... [et al.], 62(11), 961-970. https://doi.org/10.1007/s00011-013$\underline{0653-9}$

156. Li, X., Wang, X., Wang, Y., Li, X., Huang, C., \& Li, J. (2014) Inhibition of transient receptor potential melastatin 7 (TRPM7) channel induces RA FLSs apoptosis through endoplasmic reticulum (ER) stress. Clinical Rheumatology, 33(11), 1565-1574. https://doi.org/10.1007/s10067-014-2599-x

157. Bidaux, G., Roudbaraki, M., Merle, C., Crépin, A., Delcourt, P., Slomianny, C., Thebault, S., Bonnal, J. L., Benahmed, M., Cabon, F., Mauroy, B., \& Prevarskaya, N. (2005). Evidence for specific TRPM8 expression in human prostate secretory epithelial cells: functional androgen receptor requirement. Endocrine-related cancer, 12(2), 367-382. https://doi.org/10.1677/erc.1.00969

158. Zhang, L., \& Barritt, G. J. (2004). Evidence that TRPM8 is an androgendependent $\mathrm{Ca} 2+$ channel required for the survival of prostate cancer cells. Cancer research, 64(22), 8365-8373. https://doi.org/10.1158/0008-5472.CAN-04-2146

159. Yee, N. S., Zhou, W., \& Lee, M. (2010). Transient receptor potential channel TRPM8 is over-expressed and required for cellular proliferation in pancreatic 
adenocarcinoma. Cancer letters, 297(1), 49-55.

https://doi.org/10.1016/j.canlet.2010.04.023

160. Zhu, S., Wang, Y., Pan, L., Yang, S., Sun, Y., Wang, X., \& Hu, F. (2014). Involvement of transient receptor potential melastatin-8 (TRPM8) in mentholinduced calcium entry, reactive oxygen species production and cell death in rheumatoid arthritis rat synovial fibroblasts. European Journal of Pharmacology, 725, 1-9. https://doi.org/10.1016/j.ejphar.2014.01.001

161. Acharya, T. K., Tiwari, A., Majhi, R. K., \& Goswami, C. (2021). TRPM8 channel augments T-cell activation and proliferation. Cell biology international, 45(1), 198-210. https://doi.org/10.1002/cbin.11483

162. Carmeliet, P., \& Jain, R. K. (2011). Molecular mechanisms and clinical applications of angiogenesis. Nature, 473(7347), 298-307. https://doi.org/10.1038/nature10144

163. Gacche R. N. (2015). Compensatory angiogenesis and tumor refractoriness. Oncogenesis, 4(6), e153. https://doi.org/10.1038/oncsis.2015.14

164. 164. Smani, T., Gómez, L. J., Regodon, S., Woodard, G. E., Siegfried, G., Khatib, A. M., \& Rosado, J. A. (2018). TRP Channels in Angiogenesis and Other Endothelial Functions. Frontiers in physiology, 9, 1731. https://doi.org/10.3389/fphys.2018.01731

165. Huang, Y., Fliegert, R., Guse, A. H., Lü, W., \& Du, J. (2020). A structural overview of the ion channels of the TRPM family. Cell calcium, 85, 102111. https://doi.org/10.1016/j.ceca.2019.102111

166. Guo, W., \& Chen, L. (2019). Recent progress in structural studies on canonical TRP ion channels. Cell calcium, 83, 102075. https://doi.org/10.1016/j.ceca.2019.102075

167. de Oliveira, T. M., van Beek, L., Shilliday, F., Debreczeni, J. É., \& Phillips, C. (2021). Cryo-EM: The Resolution Revolution and Drug Discovery. SLAS discovery : advancing life sciences R \& D, 26(1), 17-31. https://doi.org/10.1177/2472555220960401 


\section{VITA}

Brittany was born in Chattanooga, Tennessee in 1996. She was raised in Chattanooga where she graduated from Ooltewah High School in 2014. She attended the University of Tennessee at Chattanooga and graduated cum laude with a Bachelor of Science degree in Pre-Professional Biology with a minor in Business Administration in 2018. She then attended graduate school at the University of Tennessee Health Science Center in the College of Graduate Health Sciences. During the course of her graduate studies, Brittany rotated through many laboratories involved in physiology as well cancer research. She completed her master's degree training under the mentorship of Dr. Valeria Vasquez. 